\title{
Effects of emission reductions on organic aerosol in the southeastern United States
}

\author{
C. L. Blanchard ${ }^{1}$, G. M. Hidy ${ }^{2}$, S. Shaw ${ }^{3}$, K. Baumann ${ }^{4}$, and E. S. Edgerton ${ }^{4}$ \\ ${ }^{1}$ Envair, Albany, CA, USA \\ ${ }^{2}$ Envair/Aerochem, Placitas, NM, USA \\ ${ }^{3}$ Environmental Sector, Electric Power Research Institute, Palo Alto, CA, USA \\ ${ }^{4}$ Atmospheric Research and Analysis, Cary, NC, USA \\ Correspondence to: C. L. Blanchard (cbenvair@pacbell.net)
}

Received: 26 May 2015 - Published in Atmos. Chem. Phys. Discuss.: 22 June 2015

Revised: 26 October 2015 - Accepted: 28 November 2015 - Published: 18 January 2016

\begin{abstract}
Long-term (1999 to 2013) data from the Southeastern Aerosol Research and Characterization (SEARCH) network are used to show that anthropogenic emission reductions led to important decreases in fine-particle organic aerosol (OA) concentrations in the southeastern US On average, $45 \%$ (range 25 to $63 \%$ ) of the 1999 to 2013 mean organic carbon (OC) concentrations are attributed to combustion processes, including fossil fuel use and biomass burning, through associations of measured $\mathrm{OC}$ with combustion products such as elemental carbon (EC), carbon monoxide (CO), and nitrogen oxides $\left(\mathrm{NO}_{x}\right)$. The 2013 mean combustionderived OC concentrations were 0.5 to $1.4 \mu \mathrm{g} \mathrm{m}^{-3}$ at the five sites operating in that year. Mean annual combustionderived OC concentrations declined from $3.8 \pm 0.2 \mu \mathrm{g} \mathrm{m}^{-3}$ ( $68 \%$ of total OC) to $1.4 \pm 0.1 \mu \mathrm{g} \mathrm{m}^{-3}$ (60\% of total OC) between 1999 and 2013 at the urban Atlanta, Georgia, site (JST) and from $2.9 \pm 0.4 \mu \mathrm{g} \mathrm{m}^{-3}$ (39\% of total OC) to $0.7 \pm 0.1 \mu \mathrm{g} \mathrm{m}^{-3}$ (30\% of total OC) between 2001 and 2013 at the urban Birmingham, Alabama (BHM), site. The urban OC declines coincide with reductions of motor vehicle emissions between 2006 and 2010, which may have decreased mean OC concentrations at the urban SEARCH sites by $>2 \mu \mathrm{g} \mathrm{m}^{-3}$. BHM additionally exhibits a decline in OC associated with $\mathrm{SO}_{2}$ from $0.4 \pm 0.04 \mu \mathrm{g} \mathrm{m}^{-3}$ in 2001 to $0.2 \pm 0.03 \mu \mathrm{g} \mathrm{m}^{-3}$ in 2013 , interpreted as the result of reduced emissions from industrial sources within the city. Analyses using non-soil potassium as a biomass burning tracer indicate that biomass burning OC occurs throughout the year at all sites. All eight SEARCH sites show an association of OC with sulfate $\left(\mathrm{SO}_{4}\right)$ ranging from 0.3 to $1.0 \mu \mathrm{g} \mathrm{m}^{-3}$
\end{abstract}

on average, representing $\sim 25 \%$ of the 1999 to 2013 mean OC concentrations. Because the mass of OC identified with $\mathrm{SO}_{4}$ averages 20 to $30 \%$ of the $\mathrm{SO}_{4}$ concentrations, the mean $\mathrm{SO}_{4}$-associated OC declined by $\sim 0.5$ to $1 \mu \mathrm{g} \mathrm{m}^{-3}$ as $\mathrm{SO}_{4}$ concentrations decreased throughout the SEARCH region. The 2013 mean $\mathrm{SO}_{4}$ concentrations of 1.7 to $2.0 \mu \mathrm{g} \mathrm{m}{ }^{-3} \mathrm{im}$ ply that future decreases in mean $\mathrm{SO}_{4}$-associated $\mathrm{OC}$ concentrations would not exceed $\sim 0.3$ to $0.5 \mu \mathrm{g} \mathrm{m}^{-3}$. Seasonal OC concentrations, largely identified with ozone $\left(\mathrm{O}_{3}\right)$, vary from 0.3 to $1.4 \mu \mathrm{g} \mathrm{m}^{-3}$ ( $\sim 20 \%$ of the total OC concentrations).

\section{Introduction}

In much of North America, organic aerosol (OA) represents approximately half of average $\mathrm{PM}_{2.5}$ mass concentrations in ambient air (Kanakidou et al., 2005). OA derives from primary source emissions and secondary atmospheric processes involving reactions of volatile organic compounds (VOCs) of anthropogenic and natural origins (see Appendix). The latter is widely recognized in the southeastern US with its potential source of VOCs from dense vegetation (Hand et al., 2012). Initial speculation about secondary organic aerosol (SOA) in the southeast from natural terpenoid compounds dates back to 1991 (e.g., Pandis et al., 1991). With re-evaluation of particle yields from isoprene acidic-photochemical oxidation in smog chambers, interest in natural SOA focused on this species (e.g., Kroll et al., 2006). The early 2000s investigations involving isoprene and terpenoids identified chemical mechanisms hypothetically applicable in the ambient atmo- 
sphere as well as tracers for reaction products (e.g. Hallquist et al., 2009). These hypotheses included accounting for the effect of acidity and photochemical linkages with the gas and condensed phases; a part of this chemistry involves the interactions with inorganic acids in the atmosphere - sulfur and nitrogen oxides, $\mathrm{SO}_{2}$ and nitrogen oxides $\left(\mathrm{NO}_{x}\right)$. More recently, field studies have adopted measurements from aerosol mass spectrometry combined with gas chromatograph and mass spectroscopy to track indicator species for SOA components, including species associated with isoprene-sulfur oxides or nitrogen oxides photochemistry (e.g., Gao et al., 2006; Surratt et al., 2007; Hatch et al., 2011a, b; Budisulistiorini et al., 2013; Liao et al., 2015; Lin et al., 2013, 2014; Hu et al., 2015; Kim et al., 2015; Xu et al., 2015a, b).

In parallel with advances in organic aerosol chemistry, workers explored different indirect means of estimating SOA from VOC sources. In Atlanta, Lim and Turpin (2002) used the carbon tracer method to calculate summertime SOA concentrations from collected filter samples. In the southeast, Zheng et al. $(2002,2006)$ used chemical tracers extracted from filters to identify primary OA, noting that an incomplete mass balance could be SOA. Kleindienst et al. $(2007,2010)$ and Lewandowski et al. (2013) used chemical tracers to estimate SOA from isoprene and terpenes. The carbon tracer method was expanded for natural species using carbon isotopes (e.g., Lewis et al., 2004; Tanner et al., 2004; Zheng et al., 2006; Ding et al., 2008). The empirical approaches were explored further by $\mathrm{Yu}$ et al. (2007) and Blanchard et al. (2008). Identification of water-soluble carbon as an SOA indicator also has been used (e.g. Weber et al., 2007). The various evolving methods have provided operationally defined OA as indicated schematically in Fig. S1 in the Supplement.

The characterization of SOA in the southeast is complicated by OA from open burning of vegetation (e.g., Zhang et al., 2010; Hu et al., 2015). Like other combustion sources, wildfires and prescribed burning appear to be important components of OA and SOA (e.g., Zhang et al., 2010; Hidy et al., 2014; Washenfelder et al., 2015). OA composition in the southeastern US provides indications of emission source origins, but results have not been consistent across studies (Table S1). SOA particularly is known to be a complex description of emissions, followed by evaporation, condensation, and chemical interactions during species aging in the atmosphere.

The ambiguities in accounting for OA sources and the chemistry of SOA helped motivate a major suite of field experiments during the summer of 2013: the Southern Oxidant and Aerosol Study (SOAS; http://soas2013.rutgers.edu/) and associated campaigns that comprised the Southeast Atmosphere Study (SAS; https://www.eol.ucar.edu/field_projects/ sas). Ground-level measurements were located at rural sites, with many studies situated at a Southeastern Aerosol Research and Characterization (SEARCH) network monitoring location outside Brent, near Centreville, Alabama (CTR) (e.g., Hu et al., 2015; Isaacman-VanWertz et al., 2015; Nguyen et al., 2015; Washenfelder et al., 2015; Xu et al., $2015 \mathrm{a}, \mathrm{b}$ ), a site estimated to be regionally representative (Hidy et al., 2014).

CTR and other SEARCH sites offer a long-term record of trace-gas and particle observations (Hidy et al., 2014) that provide insight into the effects of anthropogenic emission reductions on organic aerosol trends in the southeastern US The SEARCH record complements the 6-week-long SAS and SOAS investigations of key atmospheric processes and chemical reactions. Specific questions relevant to SOAS and SAS goals that can be addressed using the SEARCH data include

1. What fraction of measured organic carbon (OC) was emitted by combustion processes, such as motor vehicle exhaust and biomass burning? How has this fraction responded to emission reductions?

2. Over a long period of record, can the fractions of OA directly emitted in the condensed phase (primary organic aerosol, POA) and of SOA formed in the atmosphere via reactions of gaseous or condensed-phase precursors be quantified or constrained based on diurnal, seasonal, and annual variations of $\mathrm{OC}$, elemental (or black) carbon (EC), ozone $\left(\mathrm{O}_{3}\right)$, sulfate $\left(\mathrm{SO}_{4}\right)$, and other aerometric measurements? How have inferred SOA concentrations responded to emission reductions?

3. Do the long-term gas and particle measurements indicate how much biogenic SOA is present on daily, seasonal, or annual timescales? How has SOA of biogenic origins been affected by anthropogenic emission reductions?

This paper describes analyses of aerometric data from CTR and the other SEARCH sites that address these questions. We apply five complementary data analysis methods that provide insight into the sources of aerosol carbon in the southeast relying on the long-term SEARCH database. Because uncertainties and differences among previous studies have been challenging to resolve due to inconsistent or ambiguous definitions and terminology used to describe carbon measurements, an appendix defines terminology and identifies unresolved questions. We adopt in part the concepts of aerosol evolution from initial emission to multiscale ambient conditions postulated by Robinson et al. (2007), noting accompanying uncertainties (e.g., Murphy and Pandis, 2010).

\section{Methods}

The data for this study of aerosol carbon derive primarily from long-term SEARCH measurements obtained from up to eight operating sites, comprising four urban-rural or urbansuburban pairs, between 1999 and 2013 (e.g., Hansen et al., 2003; Hidy et al., 2014; Atmospheric Research and Analysis 
(ARA), 2014). The data set includes particle mass concentrations and composition, gases, and meteorological parameters (ARA, 2014) as previously described in Hansen et al. (2003) and Edgerton et al. (2005, 2006). Special data from ancillary experiments in the SEARCH network supplement the longterm data. We also use emission data derived from the EPA National Emission Inventory (NEI), augmented as described in Blanchard et al. (2013) and Hidy et al. (2014).

Multiple empirical methods are employed to understand OA sources and SOA formation in the southeastern US, utilizing the SEARCH data to obtain a multi-year and multiseason interpretation. The methods are (1) comparison of observations with augmented NEI emission estimates (Hidy et al., 2014) and receptor model predictions based on the NEI, (2) comparison and correlation of measured OC with EC concentrations and use of the $\mathrm{OC} / \mathrm{EC}$ ratios as indicators of combustion-related emissions and SOA formation, (3) computation of organic mass $(\mathrm{OM}) / \mathrm{OC}$ ratios utilizing $\mathrm{PM}_{2.5}$ mass and sums of species concentrations as evidence for the presence of oxidized OA, (4) estimation of biomass burning contributions to measured EC and OC using biomass burning tracers, and (5) application of receptor modeling (principal component analysis, PCA, supplemented with comparisons to positive matrix factorization, PMF) to identify and quantify atmospheric processes affecting OA concentrations. Computational details are described within the results and discussion section and in the Supplement.

\section{Results and discussion}

\subsection{Emission sources and the relation of ambient to emission trends}

This section incorporates previously published analyses by reference, extends them through 2013, and integrates findings. Results related to emission changes are compared with those obtained using other approaches in Sect. 3.6 (Synthesis).

Southeastern emissions in 2013 are shown by source category in Table S2; comparison with 2008 emissions reported in Blanchard et al. (2013) indicates reductions since 2008. Statistically significant $(p<0.001)$ relationships were found between mean annual $\mathrm{PM}_{2.5} \mathrm{EC}$ and $\mathrm{OC}$ concentrations at SEARCH sites and $\mathrm{PM}_{2.5} \mathrm{EC}$ and $\mathrm{OC}$ emissions between 1999 and 2013 (Hidy et al., 2014). Ambient EC trends were significantly related to both mobile source and total EC emissions, whereas ambient OC trends were significantly related to mobile source OC emissions but not to total OC emissions (Hidy et al., 2014). $\mathrm{PM}_{2.5}$ EC emissions in the southeastern US declined by approximately half between 1996 and 2013 due to reductions of on-road and non-road motor vehicle emissions (Hidy et al., 2014). Corresponding declines occurred in on-road and non-road motor vehicle $\mathrm{PM}_{2.5} \mathrm{OC}$ emissions, but total $\mathrm{PM}_{2.5}$ OC emissions showed little trend due to the dominance of relatively constant biomass burning emissions (Hidy et al., 2014). Mobile source OC emissions represent less than $10 \%$ of OC emissions in the southeast (Blanchard et al., 2013; Hidy et al., 2014) and only $4 \%$ as of 2013 (Table S2), with biomass burning accounting for $\sim 75 \%$ of OC emissions in emission inventories.

Using a receptor modeling approach, Blanchard et al. (2013) showed that $\mathrm{PM}_{2.5}$ EC emissions generally account for reported mean annual EC concentrations and trends in the SEARCH network (Fig. S2). Although the receptor model overpredicted EC concentrations at the Jefferson Street (JST) site in Atlanta, Georgia, and underpredicted EC concentrations at other sites, the EC trends predicted by the model from the inventory agreed with observed EC trends. Larger observed ambient EC decreases at SEARCH sites coincided with an EC emission decline occurring between 2005 and 2013 that resulted from new Environmental Protection Agency (EPA) standards for diesel engines and fuels (effective in 2007 for on-road vehicles, in mid-2010 for non-road mobile sources, and in mid-2012 for rail and marine sources) (Hidy et al., 2014). Mobile sources account for over $50 \%$ of EC emissions in the southeast prior to 2007 (Blanchard et al., 2013) and decline to $\sim 40 \%$ by 2013 (Table S2), so ambient EC concentrations are expected to decrease with declining mobile source EC emissions.

Contrasting with results for EC (as well as carbon monoxide $(\mathrm{CO}), \mathrm{NO}_{x}$, and $\mathrm{SO}_{x}$ ), greater differences between receptor model-predicted OC and measured OC trends were observed (Fig. S3). These differences occurred even when comparing model predictions to the fraction of measured OC that was not associated with $\mathrm{O}_{3}$ and $\mathrm{SO}_{4}$ (inventory OC emissions do not represent SOA deriving from biogenic emissions of isoprene and other gases). Ambient OC trends were more pronounced than trends predicted by the model from the inventory (Fig. S3). However, the receptor model reproduces observed OC trends more readily for sites where the mobile source contribution is greatest (Fig. S3). Receptor-modeling studies have consistently identified mobile source contributions to ambient $\mathrm{PM}_{2.5}$ mass concentrations in Atlanta and Birmingham (e.g., Zheng et al., 2002; 2006; Baumann et al., 2008; Lee et al., 2009); a recent analysis indicated that mobile sources contributed 0.8 to $2.8 \mu^{-3} \mathrm{~m}^{-3}$ to $2006-2010$ $\mathrm{PM}_{2.5}$ mass concentrations (between 6-7 and 19-21\% of $\mathrm{PM}_{2.5}$ mass) in Atlanta and Birmingham (Watson et al., 2015). Measured ambient concentrations of non-polar $\mathrm{PM}_{2.5}$ OC species associated with motor vehicles, such as hopanes and steranes, declined substantially $(>50 \%)$ at Birmingham, Alabama (BHM) and JST between 2006 and 2010, linking mobile source emission reductions during those years with observed decreases in urban OC concentrations (Blanchard et al., 2014a). As noted in the Appendix, emitted OC is not conservative, but is affected by evaporation and possibly recondensation as secondary species, or by augmentation by SOA derived from gas-phase emissions. A possible explanation for the observed OC trends is that diesel SOA concentra- 
tions (which were not incorporated in the receptor model predictions) were greater prior to adoption of new diesel emission regulations beginning in 2007. In addition, changes in gasoline-engine SOA concentrations may have occurred. Reductions of $\mathrm{SO}_{2}$ emissions are also thought to have changed $\mathrm{SO}_{4}$-associated SOA concentrations over time (Xu et al., 2015a, b), but the chemical mass balance (CMB) model is set up to predict $\mathrm{OC}$ that is not associated with $\mathrm{O}_{3}$ and $\mathrm{SO}_{4}$ (Blanchard et al., 2013).

Trends in mobile source VOC emissions paralleled trends in mobile source $\mathrm{PM}_{2.5} \mathrm{OC}$ and $\mathrm{EC}$ emissions (Hidy et al., 2014; Blanchard et al., 2013). Similar to OC emissions, mobile source VOC emissions in the southeastern US declined by approximately half between 1996 and 2013 due to reductions of on-road and non-road motor vehicle emissions (Hidy et al., 2014), but total VOC emissions showed little trend due to dominance by relatively constant VOC emissions from vegetation and soils (Table S2).

In summary, emission trends partially explain observed ambient EC and OC trends. For OC, the link between inventory emissions and ambient concentrations is less definitive than is the case for links between reductions of $\mathrm{EC}, \mathrm{CO}$, $\mathrm{NO}_{x}$, and $\mathrm{SO}_{2}$ emissions and observed trends in ambient $\mathrm{EC}$, $\mathrm{CO}, \mathrm{NO}_{y}, \mathrm{SO}_{2}$, and $\mathrm{PM}_{2.5} \mathrm{SO}_{4}$ concentrations (Hidy et al., 2014).

\subsection{Ambient EC and OC concentrations and trends}

Trends and spatial variations are evident for mean annual and seasonal EC and OC concentrations (Table 1 and Fig. 1). Mean EC concentrations were 2.0 to 3.5 times greater at JST than at CTR, thereby indicating two- to threefold greater influence of combustion sources within Atlanta compared to rural CTR because EC is a tracer of combustion (Appendix). Mean OC concentrations were 1.0 to 1.8 times greater at JST than at CTR, indicating urban sources of OC possibly superimposed on a relatively high regional baseline. The ratio of JST EC to CTR EC declined from $2.8: 1$ to $2.1: 1$ between the first and third 5-year periods, while the JST OC to CTR OC ratio decreased from $1.5: 1$ to $1.2: 1$ between the first and third 5-year periods. Since the ratio of JST EC / CTR EC declined by $25 \%$ and the ratio of JST OC / CTR OC declined by $20 \%$, the decreases are comparable but the difference is consistent with a greater mobile source influence at JST than at CTR. Both EC and OC concentrations exhibit decreasing trends at all SEARCH sites (Hidy et al., 2014), particularly after 2007 but with a possible rise between 2009 and 2011 (Fig. 1). Higher mean monthly concentrations in 2011 were followed by further decline in 2012 and 2013 (Fig. 1). Whereas long-term ambient EC and OC trends are predicted by EC and OC mobile source emission reductions (Sect. 3.1), changes between 2008 and 2013 are predicted from the emission inventory for EC (Fig. S2) but not for OC (Fig. S3).

No season consistently exhibits the highest mean EC and OC concentrations but the CTR mean OC concentrations

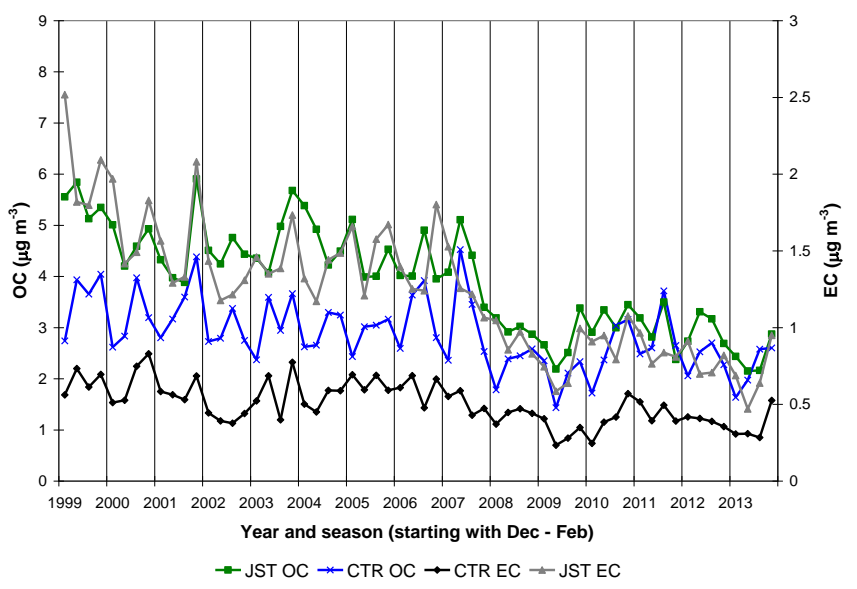

Figure 1. Seasonal mean EC and OC concentrations at CTR and JST. All correlations among the four time series are statistically significant ( $p<0.05$ ): CTR EC and OC, $r=0.68$ (95\% CI 0.52-0.80); JST EC and OC, $r=0.87$ (95\% CI 0.79-0.92); CTR EC and JST $\mathrm{EC}, r=0.76$ (95\% CI 0.62-0.85); CTR OC and JST OC, $r=0.68$ (95\% CI 0.51-0.79).

and $\mathrm{OC}$ / EC ratios are highest during summer, interpreted as the influence of aging and SOA formation during warmer months. In contrast, JST mean OC and EC concentrations tend to be higher during autumn and winter (Table 1). In 2013 , the ratios of OC to total carbon $(\mathrm{TC}=\mathrm{EC}+\mathrm{OC})$ in daily-average filter samples were greatest at CTR during the SOAS campaign (Fig. S4). This result suggests that rates of SOA formation at CTR during SOAS exceed SOA formation rates at other sites in the region and at other times of the year. The differences between JST and CTR mean summer OC concentrations decline from $1.1 \mu \mathrm{g} \mathrm{m}^{-3}$ in 1999-2003 to less than $0.1 \mu \mathrm{g} \mathrm{m}^{-3}$ in 2009-2013, interpreted as reductions of urban OC concentrations toward a regional baseline level (Table 1).

Mean OC / EC ratios are higher at CTR than at JST, again consistent with regional-scale aging of ambient aerosol and a relatively greater influence of SOA at CTR. The period mean OC / EC ratios at JST range from 2.3: 1 to $4.0: 1$, suggesting variable contributions from multiple sources. For comparison, typical OC / EC ratios are $\sim 1$ in freshly emitted motor vehicle emissions (Chow et al., 2004), with important differences among vehicle types (McDonald et al., 2015), 5:120: 1 in near-source biomass burning plumes (Andreae et al., 1996; Andreae and Merlet, 2001; Hobbs et al., 1996; Lee et al., 2005), and potentially much greater than unity as oxidation and SOA formation proceed (Robinson et al., 2007).

Temporal trends in ambient EC and OC correlated within individual sites and across the SEARCH domain (e.g., CTR and JST, Fig. 1), indicating regional coherence of trends and seasonal variations for both EC and OC. The strong correlation of EC and OC at all SEARCH sites, averaging times (annual, seasonal, monthly, daily), and seasons (Table S3, Fig. S5) indicates that combustion processes are a major 
Table 1. In total, 5-year seasonal mean EC and OC concentrations at CTR and JST with mean OC / EC ${ }^{\mathrm{a}}$.

\begin{tabular}{lrrrrrr}
\hline Period $^{\mathrm{b}}$ & CTR EC & CTR OC & CTR OC / EC & JST EC & JST OC & JST OC / EC \\
\hline $1999-2003 \mathrm{~W}$ & $0.490 \pm 0.025$ & $2.615 \pm 0.154$ & 5.34 & $1.725 \pm 0.068$ & $4.801 \pm 0.153$ & 2.78 \\
$1999-2003 \mathrm{Sp}$ & $0.607 \pm 0.030$ & $3.411 \pm 0.154$ & 5.62 & $1.410 \pm 0.037$ & $4.465 \pm 0.096$ & 3.17 \\
$1999-2003 \mathrm{Su}$ & $0.537 \pm 0.020$ & $3.541 \pm 0.100$ & 6.59 & $1.439 \pm 0.035$ & $4.664 \pm 0.090$ & 3.24 \\
$1999-2003 \mathrm{~A}$ & $0.684 \pm 0.026$ & $3.814 \pm 0.145$ & 5.58 & $1.808 \pm 0.060$ & $5.264 \pm 0.150$ & 2.91 \\
2004-2008 W & $0.538 \pm 0.036$ & $2.348 \pm 0.167$ & 4.37 & $1.319 \pm 0.050$ & $4.099 \pm 0.125$ & 3.11 \\
2004-2008 Sp & $0.556 \pm 0.029$ & $3.269 \pm 0.199$ & 5.88 & $1.173 \pm 0.034$ & $4.283 \pm 0.135$ & 3.65 \\
2004-2008 Su & $0.528 \pm 0.030$ & $3.267 \pm 0.151$ & 6.19 & $1.292 \pm 0.032$ & $4.114 \pm 0.077$ & 3.19 \\
2004-2008 A & $0.551 \pm 0.024$ & $2.850 \pm 0.120$ & 5.17 & $1.375 \pm 0.049$ & $3.852 \pm 0.093$ & 2.30 \\
2009-2013 W & $0.402 \pm 0.027$ & $2.066 \pm 0.136$ & 5.14 & $0.859 \pm 0.060$ & $2.828 \pm 0.155$ & 3.29 \\
2009-2013 Sp & $0.354 \pm 0.018$ & $2.243 \pm 0.117$ & 6.34 & $0.699 \pm 0.039$ & $2.774 \pm 0.128$ & 3.97 \\
$2009-2013 \mathrm{Su}$ & $0.357 \pm 0.017$ & $2.818 \pm 0.112$ & 7.89 & $0.723 \pm 0.024$ & $2.870 \pm 0.095$ & 3.97 \\
$2009-2013 \mathrm{~A}$ & $0.437 \pm 0.024$ & $2.579 \pm 0.105$ & 6.31 & $0.926 \pm 0.042$ & $2.934 \pm 0.110$ & 3.05 \\
\hline
\end{tabular}

${ }^{a}$ Uncertainties are 1 standard error of the means. OC / EC is computed as ratios of means. Propagation of errors yields 1 standard error of OC / EC ranging from 0.30 to 0.49 for CTR (mean 0.41) and 0.10 to 0.29 for JST (mean 0.16). ${ }^{\mathrm{b}} \mathrm{W}$ is December, January, February; Sp is March, April, May; Su is June, July, August; A is September, October, November.

source of OC. However, significant correlations of $\mathrm{SO}_{4}$ with both $\mathrm{EC}$ and $\mathrm{OC}$ during summer suggest the influence of $\mathrm{SO}_{4}$ on SOA formation in summer, consistent with results from SOAS (Xu et al., 2015a, b; Budisulistiorini et al., 2015). OC correlates with both $\mathrm{EC}$ and $\mathrm{SO}_{4}$, but for different reasons. Consequently, $\mathrm{EC}$ and $\mathrm{SO}_{4}$ also correlate, but not as strongly and not as consistently across timescales. In summary, the EC and OC measurements indicate influence of multiple emission sources or atmospheric processes affecting all SEARCH sites, though differently at urban and rural locations.

\subsection{OM / OC ratios}

More oxygenated $\mathrm{OA}$ has higher ratios of $\mathrm{OM} / \mathrm{OC}$, so $\mathrm{OM} / \mathrm{OC}$ potentially serves as an indicator of atmospheric aging (Turpin and Lim, 2001). A low value (e.g., $\mathrm{OM} / \mathrm{OC} \sim 1.4$ to 1.6 ) suggests little aging (i.e., POA is a large fraction of $\mathrm{OA}$ ), whereas a high value (e.g., > 2) suggests more aging (SOA is a large fraction of OA). For comparison, OM / OC ratios are 1.2 for pentane (and higher molecular weight alkanes), 1.1 for isoprene, and 2.0 for isoprene epoxydiol (IEPOX) (a gas-phase intermediate of isoprene oxidation, yielding SOA). The average motor vehicle $\mathrm{OM} / \mathrm{OC}$ ratio is $\sim 1.2$ to 1.4 (Landis et al., 2007) while biomass burning $\mathrm{OM} / \mathrm{OC}$ averages $\sim 1.4$ to 1.8 (Reid et al., 2005).

We estimate the $\mathrm{OM} / \mathrm{OC}$ ratio for the urban and rural SEARCH sites using a mass balance computation based on particle composition. The sum of species concentrations, including estimated particle-bound water (PBW) at laboratory temperature and relative humidity $(\mathrm{RH})$, is

$$
\begin{aligned}
\text { Sum of species } & =f_{1} \times \mathrm{SO}_{4}+f_{2} \times \mathrm{NO}_{3}+f_{3} \times \mathrm{NH}_{4} \\
& +\mathrm{EC}+\mathrm{OC}+\mathrm{MMO}+\mathrm{Na}+\mathrm{Cl}
\end{aligned}
$$

(inorganic species concentrations are from ion measurements). PBW at laboratory RH of $<38 \%$ is represented by the coefficients $f_{1}$ (1.28), $f_{2}(1.15)$, and $f_{3}$ (1.25) (Tombach, 2004, as derived from Tang, 1996). The coefficient $f_{1}$ is an average of the coefficients for $\mathrm{NH}_{4} \mathrm{HSO}_{4}$ (1.27) and $\left(\mathrm{NH}_{4}\right)_{2} \mathrm{SO}_{4}$ (1.29), $f_{2}$ is the coefficient for $\mathrm{NH}_{4} \mathrm{NO}_{3}$, and $f_{3}$ is a weighted average reflecting higher $\mathrm{SO}_{4}$ than $\mathrm{NO}_{3}$ concentrations. MMO is the sum of the concentrations of six crustal elements ( $\mathrm{Al}, \mathrm{Ca}, \mathrm{Fe}, \mathrm{K}, \mathrm{Si}, \mathrm{Ti})$ (X-ray fluorescence (XRF) spectroscopy measurements), expressed as oxides (Hansen et al., 2003). This estimate of crustal mass is likely conservative, since it does not include $\mathrm{Mg}$ or $\mathrm{Mn}$ and the assumed $\mathrm{Ca}$ mass (as $\mathrm{CaO}$ ) would be less than the mass of $\mathrm{CaCO}_{3}$ (if present). The carbon components, metals, and chloride are not adjusted for retained water at laboratory temperature and humidity. This creates a potential for uncertainty in the calculation, especially in the case of OC. Atmospheric OC is known to be hygroscopic at elevated humidity, but experimental data suggest that water retention is mini$\mathrm{mal}$ at $<38 \% \mathrm{RH}$ for laboratory filter analysis (e.g., Malm et al., 2005; Taylor et al., 2011). Measurements made during SOAS indicate that organic-associated water was less than $\sim 25 \%$ of total particle water in mid-day ambient samples when ambient RH was less than $\sim 50 \%$ (Guo et al., 2015). We estimate an OC PBW uncertainty in Eq. (1) by assuming that $\mathrm{OC}$ PBW is $10 \%$ of $\mathrm{OC}\left(f_{\mathrm{OC}}=1.1\right)$, which would increase the calculated sum of species by $3 \%$ and decrease the OM / OC (calculated below) by 0.1 units on average.

The difference between $\mathrm{PM}_{2.5}$ mass and the sum of species concentrations is denoted as non-measured (NM) mass:

$\mathrm{NM}$ mass $=\mathrm{PM}_{2.5}$ mass - Sum of species.

An upper bound for $\mathrm{OM}$ is calculated as $\mathrm{OM}^{*}=\mathrm{OC}+\mathrm{NM}$ mass, which assumes that all NM mass is associated with OA. Any mass that is missing from the computed sum of 
species would bias NM mass high, thereby also causing OM* to be higher than the true OM. Similarly, underestimation of PBW would bias NM mass and OM* high. We estimate the combined effect of missing species and PBW to result in possible overestimation of $\mathrm{OM}^{*}$ / OC by up to 0.2 units on average. An opposing bias potentially arises in Eq. (2), because the FRM sampler that is used by SEARCH to provide the $\mathrm{PM}_{2.5}$ mass measurement is known to lose volatile species (e.g., inorganic particle $\mathrm{NO}_{3}$ ). We recalculated Eq. (1) by replacing the measured $\mathrm{NO}_{3}$ and $\mathrm{Cl}$ concentrations (which are the sum of a Teflon front filter and a nylon backup filter located in the SEARCH PCM sampler) with the Teflon filter concentrations. The effect was to reduce the calculated sum of species, which then increased the calculated $\mathrm{OM}^{*} / \mathrm{OC}$ by 0.2 units on average. Therefore, we estimate the uncertainty in the calculated $\mathrm{OM}^{*} / \mathrm{OC}$ ratios as \pm 0.2 units. If no PBW is associated with inorganic species $\left(\mathrm{SO}_{4}, \mathrm{NO}_{3}\right.$, $\mathrm{NH}_{4}$ ), Eq. (1) would underestimate $\mathrm{OM}^{*} / \mathrm{OC}$ by 0.5 units on average. However, inorganic PBW is expected even at $\mathrm{RH}<38 \%$, so this potential bias appears less plausible than the documented bias in FRM PM 2.5 mass concentrations.

At all SEARCH sites, NM mass concentrations averaged 1.5 to $1.9 \mu \mathrm{g} \mathrm{m}^{-3}$ (interquartile range $\sim 0.5$ to $\sim 2.5 \mu \mathrm{g} \mathrm{m}^{-3}$ at all except (rural) Yorkville, Georgia (YRK)) during the most recent 5-year period (2009 to 2013; $\mathrm{Na}$ and $\mathrm{Cl}$ ions were not measured prior to 2008) (Fig. S6). Daily NM mass correlated with daily $\mathrm{OC}$ to varying degrees: $r^{2}$ was $0.2-0.3$ at BHM, Gulfport, Mississippi (GFP), (rural) Oak Grove, Mississippi (OAK), and 0.4-0.5 at CTR, JST, YRK, (suburban) Outlying Landing Field, Pensacola, Florida (OLF), and Pensacola, Florida (PNS). The average OM* / OC varied by site from 1.5 (BHM) to 2.0 (YRK) (Fig. 2) ( $\Delta \mathrm{OM}^{*} / \Delta \mathrm{OC}$ regression slopes of 1.6 to 1.9 without intercept terms, Fig. S7), which suggests a regionally characteristic but spatially and temporally variable mix of less-oxidized and more-oxidized $\mathrm{OA}$. The consistency of the mean values in the range of 1.5 to $2.0( \pm 0.2)$ indicates that relatively fresh emissions contribute a major portion of $\mathrm{OA}$ at both urban and rural sites with variations in the degree of oxidation or SOA mass. However, higher $\mathrm{OM}^{*} / \mathrm{OC}$ and $\mathrm{OM}^{*} / \mathrm{EC}$ occur in the warmest months (Fig. 2), consistent with seasonal SOA formation and the seasonal variations discussed above. Our mean $\mathrm{OM}^{*} / \mathrm{OC}$ is lower than reported in SOAS research for example, mean CTR OM / OC of 2.16 from aerosol mass spectroscopy (AMS) measurements (Xu et al., 2015a). For identical sampling periods, our spring 2012 mean OM* / OC was 1.34 at JST and 1.80 at YRK, which is lower than mean OM / OC of 1.93 at JST and 1.98 at YRK reported by Xu et al. (2015b). Our winter 2012-2013 mean OM* / OC was 1.51 at JST and 1.56 at YRK, which is higher than mean OM / OC of 1.40 at JST and 1.31 at YRK reported by Xu et al. (2015b). Comparisons are discussed further in Sect. 3.5.3.
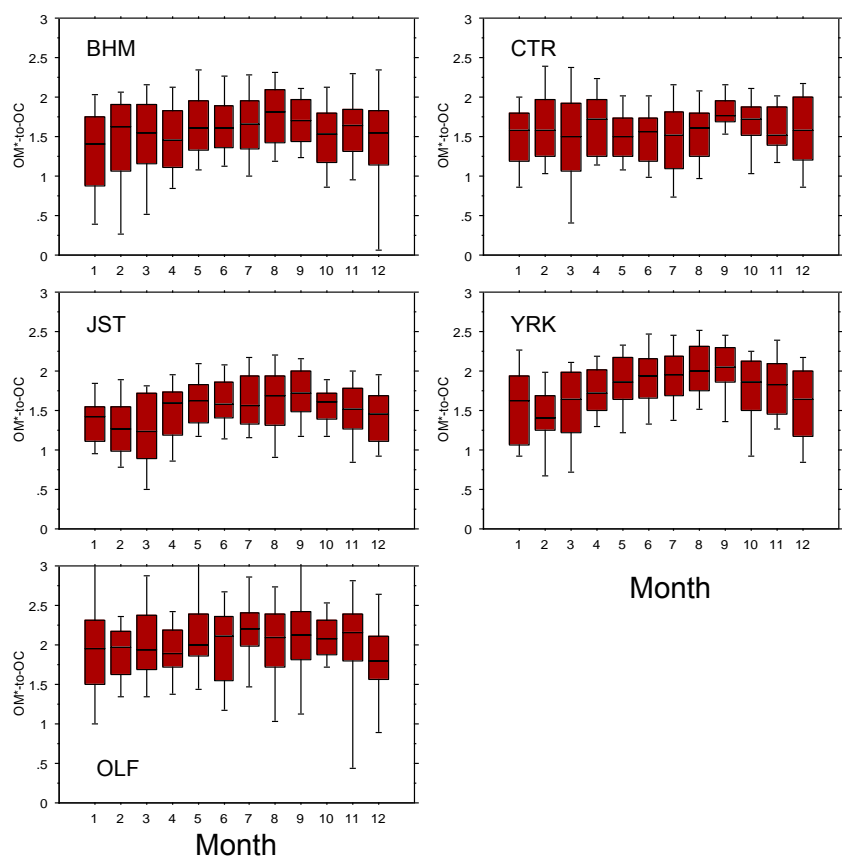

Month

Figure 2. Statistical distributions of the ratio $\mathrm{OM}^{*} / \mathrm{OC}$ computed for daily-average measurements at SEARCH sites, 2009-2013. The distributions show the 10th, 25th, 50th, 75th, and 90th percentiles. $\mathrm{OM}^{*}$ is the sum of measured $\mathrm{OC}$ and the computed difference of $\mathrm{PM}_{2.5}$ mass minus the sum of measured species concentrations.

\subsection{Biomass burning}

Emission inventories indicate that biomass burning, including prescribed burns, wildfires, agricultural burns, and domestic heating, is the largest source of $\mathrm{PM}_{2.5}$ OC emissions in the southeast on an annual-average basis (Hidy et al., 2014). Prescribed burns are the largest source of biomass burning OC emissions, again on an annual basis (Hidy et al., 2014). In the southeast, prescribed burns are employed to manage roughly 4 million hectares (ha) $(\sim 10$ million acres) of land every year, primarily between January and April; wildfires may occur year-round but are more frequent in warmer months (Wade et al., 2000; Haines et al., 2001). Nearby (e.g., $\sim 10 \mathrm{~km}$ ) biomass burning plumes are sometimes evident in CTR hourly data and substantially affect observed concentrations of EC, $\mathrm{OA}, \mathrm{CO}, \mathrm{NO}_{y}, \mathrm{NH}_{3}$, and $\mathrm{O}_{3}$ (Fig. S8). However, the cumulative effect of widespread and potentially wide-ranging biomass burning on long-term ambient OA concentrations is more difficult to determine. The available data record does not include organic biomass burning tracers, such as levoglucosan, except during special studies such as the 6-week SOAS campaign. Alternatively, nonsoil potassium $(\mathrm{K})$ has been used as an indicator of biomass combustion in previous studies (Calloway et al., 1989; Lewis et al., 1988; Lewis, 1996; Pachon et al., 2010, 2013) and can be determined from $\mathrm{K}$ measurements reported in the longterm SEARCH data. Using a single tracer species to identify 
and quantify biomass burning contributions to ambient $\mathrm{OA}$ is subject to important uncertainties, and potassium is an imperfect tracer of biomass burning. Zhang et al. (2010), for example, showed that water-soluble $\mathrm{K}$ and levoglucosan correlate in winter (when more biomass burning occurs in the southeastern US) but not in summer. However, levoglucosan and its associated AMS markers may persist in the atmosphere for less than a day (May et al., 2012; Bougiatioti et al., 2014). Instability of organic marker species could lead to differences in AMS biomass burning OA compared with estimates made using $\mathrm{K}$ as a tracer.

Non-soil K (nsK) is estimated from coarse PM ( $\mathrm{PM}_{\text {coarse }}$ or $\mathrm{PM}_{\text {crs }}$, $\mathrm{PM}$ between 2.5 and $10 \mu \mathrm{m}$ ) and $\mathrm{PM}_{2.5}$ XRF measurements of $\mathrm{K}$ and $\mathrm{Si}$ following the $\mathrm{K}$ tracer approach of Pachon et al. (2013). Briefly, the method regresses measured $\mathrm{K}$ against species $X$ concentrations: $\mathrm{K}=\alpha+\beta \times X$ (where $X$ derives primarily from crustal material). Si measurements are used to represent the crustal species, $X$, because Si concentrations are routinely well above the limits of detection and the correlations of $\mathrm{Si}$ with $\mathrm{Al}$ and other known crustal elements indicate few or no interfering sources of Si. The correlations of $\mathrm{PM}_{\text {coarse }} \mathrm{XRF} \mathrm{K}$ and $\mathrm{Si}$ are very strong, with consistent values of the slope $\beta=\Delta \mathrm{K} / \Delta \mathrm{Si}$ of 0.10 to 0.13 and $r^{2} \sim 0.8$ at all sites (Figs. S9-S11). These slopes therefore define the expected ratio of $\mathrm{K} / \mathrm{Si}$ in crustal material in the region. The ratios are lower than, but consistent with, a value of $0.15 \pm 0.01$ reported for data from Phoenix, AZ (Lewis et al., 2003). In contrast to $\mathrm{PM}_{\mathrm{crs}}, \mathrm{PM}_{2.5}$ measurements exhibit large excesses of $\mathrm{K}$ over the expected $\mathrm{K} / \mathrm{Si}$ ratios, indicating the presence of one or more non-crustal sources of $\mathrm{PM}_{2.5} \mathrm{~K}$ (Figs. S9 to S11). For each plot, fine-particle K vs. Si forms one branch that falls on the line defined by coarse-particle $\mathrm{K}$ vs. Si, indicating similar relationships between $\mathrm{K}$ and $\mathrm{Si}$ within fine and coarse fractions of crustal PM. High fineparticle $\mathrm{K}$ concentrations also occur at lower-than-average fine $\mathrm{Si}$ concentrations. We apply the slopes $\beta$ to compute $\mathrm{nsK}=\mathrm{K}-\beta *$ Si from $\mathrm{PM}_{2.5}$ data (Fig. S9). The agreement between computed nsK and measured water-soluble $\mathrm{K}(\mathrm{K}$ ion, KI; measured beginning 2008) supports the interpretation of non-soil $\mathrm{K}$ as an indicator of biomass burning $\mathrm{K}$ (Kbb) (which is water soluble) at rural inland sites such as CTR (Fig. S9). Although computed Kbb exceeds measured $\mathrm{K}$ ion concentrations by $\sim 0.02-0.03 \mu \mathrm{g} \mathrm{m}^{-3}$ on average, the difference may relate to the differing resolutions and sensitivities of the XRF and ion measurements (Fig. S9). Later analyses (Sect. 3.5.2) link CTR Kbb with species (including $\mathrm{CO}$ and EC) deriving from combustion. Possibly, both $\mathrm{K}$ ion and computed nsK could also have a marine origin at some coastal sites (e.g., OLF) or an industrial process origin at some urban sites (e.g., BHM). Detailed review of computed nsK indicated that all $\mathrm{nsK}>0.4 \mu \mathrm{g} \mathrm{m}^{-3}$ occurred on or 1 day after the 4 July and 1 January US holidays, and only at urban sites (Fig. S11). This result appears to indicate fireworks as a source of nsK on such occasions. Other than samples from 1 and 2 January and from 4 and 5 July, we identify
nsK as biomass burning $\mathrm{K}$ (Kbb), recognizing some uncertainty in this identification for BHM and coastal sites. Since nsK can be computed from the XRF measurements of $\mathrm{K}$ and Si for the full SEARCH record (1999 to 2013), whereas K ion measurements commenced in 2008, we use nsK as our biomass burning tracer. After exclusion of obvious high-K events (holiday fireworks), our identification of nsK as an indicator of biomass burning (Kbb) could introduce a bias toward overestimation in the calculation of OCbb, discussed below, if other sources of water-soluble $\mathrm{K}$ are important.

The ratio of $\mathrm{TC}$ to $\mathrm{Kbb}$ (TCbb / Kbb) in biomass burning is known to vary widely among fire types (e.g., wildfires differ from prescribed burns) and among fire stages (e.g., temperature, or flaming vs. smoldering). The variability of emissions among and within fires implies that biomass burning tracers are more useful for estimating average impacts than for quantifying burn contributions during individual events. We use a single average scaling factor based on consideration of emissions information (Hidy et al., 2014), which we check using the correlation of modern $\mathrm{C}$ with non-soil K (Fig. S12). Inventory annual-average $\mathrm{TCbb} / \mathrm{Kbb}$ for fires is in the range 28:1-36:1 (Blanchard et al., 2013). For fires (prescribed burns, wildfire, agricultural field burns) plus area sources (largely open burning from agricultural, construction, and yard waste), the 2013 ratio of TCbb / Kbb is $\sim 23: 1$ (Table $\mathrm{S} 2$ ). The ratio varies among emission source profiles from lower values of 5:1 and 7:1 (solid waste combustion and agricultural burning, respectively) to an intermediate value of $19: 1$ (wildfire) and higher values of $43.5: 1$ (slash burning) and $61: 1$ (residential wood combustion) (EPA, http://www. epa.gov/ttn/chief/software/speciate/; Reff et al., 2009). Our assumed fixed scaling factor of 32 for TCbb / Kbb is similar to carbon-isotope data from CTR winter samples (Fig. S12, CTR regression slope $\Delta \mathrm{TC}_{\text {modern }} / \Delta \mathrm{Kbb}=43$ ), when prescribed burns are more common and SOA formation rates are lower. The higher slope of $\Delta \mathrm{TC}_{\text {modern }} / \Delta \mathrm{Kbb}=71: 1$ at JST could reflect a different type of biomass burning (e.g., residential wood combustion), while the lesser correlation of modern TC with non-soil K (assumed to represent $\mathrm{Kbb}$ ) at BHM and higher slope at PNS potentially reflect source variability or the confounding influence of industrial (BHM) or marine (PNS) sources of non-soil K. The mean ratio of wood-burning OC concentrations determined by Kleindienst et al. (2010) using organic tracers (20 samples, collected in May and August 2005, paired by site and date) to Kbb concentrations is $20: 1$ (varying by site from $16: 1$ at BHM and CTR to $18: 1$ at PNS and 29:1 at JST). This result agrees with the inventory $\mathrm{TCbb} / \mathrm{Kbb}$ of $\sim 23: 1$ averaged across fires and area sources (Table S2) assuming that the corresponding ratio of wood-burning $\mathrm{TC} / \mathrm{Kbb}$ is $\sim 10 \%$ higher than wood-burning OC/Kbb. Since prescribed burns and residential wood combustion (higher TCbb / Kbb) generally occur during winter months, whereas wildfires, agricultural field burns, and waste burning (lower TCbb / Kbb) may occur during warmer months, our assumed fixed scal- 
ing factor of $32: 1$ for TCbb / Kbb likely fails to capture some of the seasonal variability in TCbb. A higher scaling ratio (e.g., $\Delta \mathrm{TCbb} / \Delta \mathrm{Kbb}=32$ rather than 20) would yield higher computed TCbb and therefore higher OCbb. Based on $\triangle \mathrm{OC} / \triangle \mathrm{EC}$ in actual biomass burning events observed at SEARCH sites (Fig. S8), we compute OCbb $=0.9 \times \mathrm{TCbb}$ (the ratio $\mathrm{OCbb} / \mathrm{TCbb}$ could be higher in some burn events). Considering the range among SEARCH sites of winter $\Delta \mathrm{TC}_{\text {modern }} / \Delta \mathrm{Kbb}(22: 1$ to $82: 1$, Fig. S12), the variability of $\mathrm{TCbb} / \mathrm{Kbb}$ among source types, and the possibility that $\mathrm{Kbb}$ could be overestimated if there are sources other than biomass burning that contribute to nsK, we estimate the uncertainty range for $\mathrm{OCbb}$ as $-50 \%$ to $+100 \%$ (factor of 2) subject to the constraint that $\mathrm{OCbb}<\mathrm{OC}$.

CTR monthly average concentrations indicate a downward trend in OC but not in computed OCbb, so that OCbb has become a larger fraction of OC at CTR since 2007 (Fig. 3). The absence of trend in computed OCbb reflects the absence of trend in measured $\mathrm{K}$ and computed nsK. OCbb tends to be higher in winter months, when prescribed burns are more common and residential heating needs are greatest, but $\mathrm{OCbb}$ is present during all seasons (Fig. 3) and at all SEARCH sites (Fig. S13). Retene, a tracer of coniferous wood combustion, is evident at the sites where it was measured (urban BHM and JST) with a pronounced seasonal cycle (Fig. S14). This seasonality could indicate that the summer OCbb has been overestimated, or it could indicate that retene loss rates are greater during warmer months. Retene emissions from prescribed burning in the southeast are highly variable and depend largely on the amount of softwood present in the fuel. Since historical fire suppression has led to the accumulation of significant amounts of hardwood in a thick mid-story of pine-dominated forests (e.g. Provencher et al., 2001; Varner et al., 2005), retene is not considered a unique indicator for prescribed burning emissions in the southeast.

The analysis of $\mathrm{K}$ measurements from the SEARCH data reinforces the conclusion that biomass burning is an important component of combustion-related OA in the SEARCH domain, at all sites and in all seasons. The contribution is especially important for regional-scale OA, as suggested by the CTR data. Uncertainties in the estimation procedure and scaling factors imply that our computed CTR mean OCbb $\left(1.6 \mathrm{\mu g} \mathrm{m}^{-3}, 1999-2013\right.$ average) could be up to twice as high as the true mean OCbb concentration. If so, actual mean 1999-2013 OCbb would be $0.8 \mu \mathrm{g} \mathrm{m}^{-3}$, which is higher than AMS mean biomass burning OA $\left(10 \%\right.$, or $\sim 0.25 \mu \mathrm{g} \mathrm{m}^{-3}$ OC) at CTR during the 6-week SOAS period (Xu et al., 2015a, b). Although the majority of brown carbon aerosol mass during SOAS is attributed to biomass burning rather than to SOA, biomass burning did not contribute the majority of OA (Washenfelder et al., 2015). As previously noted, more biomass burning occurs in the southeastern US during cooler months than during mid-summer (Zhang et al., 2010), so the SOAS campaign is expected to show less biomass burning than during other months. Reported AMS

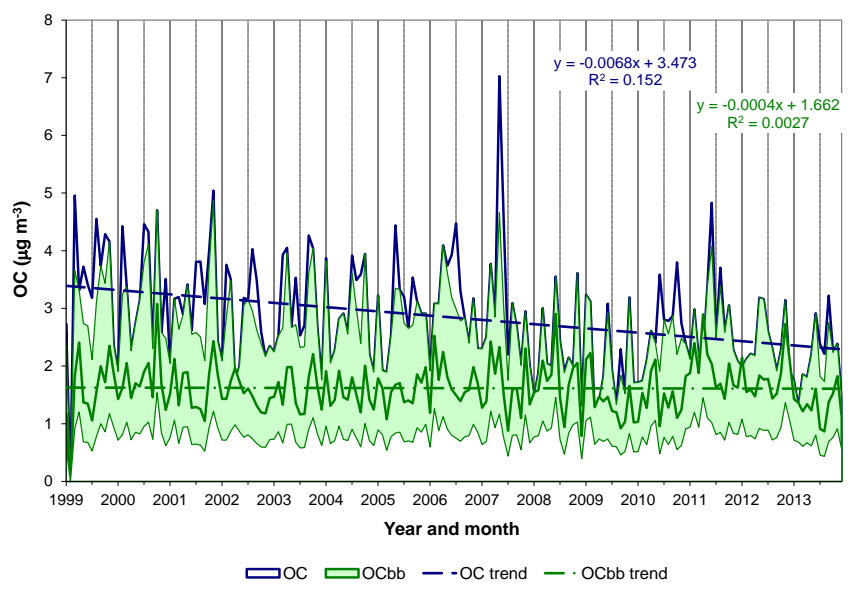

Figure 3. Monthly average measured OC (solid blue line) and computed biomass burning OCbb (solid green line with surrounding shaded area indicating estimated uncertainty) at CTR. Trends in OC (dashed blue line) are statistically significant $(p<0.05)$; trends in OCbb (dashed green line) are not statistically significant.

mean biomass burning OA concentrations were higher at JST $\left(\sim 0.5 \mu \mathrm{g} \mathrm{m}^{-3}\right.$ OC during May and December 2012) and at YRK $\left(\sim 0.6 \mu \mathrm{g} \mathrm{m}^{-3}\right.$ OC during December 2012 and January 2013) (Xu et al., 2015a, b). Due to the loss of organic tracers on a timescale of about a day or less, the biomass burning OA that is estimated using AMS is thought to yield an estimate of relatively fresh burning as compared to aged regional burning levels (Xu et al., 2015a, b). Estimates of a regional pool of more aged biomass burning OA are not available. If the reported AMS biomass burning OA concentrations are, e.g., $\sim 50 \%$ lower than the sum of fresh and aged biomass burning OA, the resulting sum $\left(1 \mu \mathrm{g} \mathrm{m}^{-3} \mathrm{OC}\right)$ would fall within our OCbb uncertainty range. The lack of long-term trend in OCbb (Fig. 3) occurs regardless of scaling uncertainties (assuming constant scaling of OCbb to $\mathrm{Kbb}$ ), because no trend exists in either $\mathrm{K}$ or Kbb concentrations.

\subsection{Principal component analysis}

Important insight into the origins of ambient aerosol can be obtained with multivariate statistical methods, such as PCA, which is a well-established method for PM source apportionment (Dattner and Hopke, 1982). PCA generates mathematically independent groupings of measurements based on the correlations among the measured variables (classically, the groups are geometrically orthogonal to one another). The number of groups reproduces as large a fraction of the total variance of a data set as possible subject to optimization criteria, typically explaining $\sim 75$ to $80 \%$ of the variance of, e.g., $\sim 20$ to 25 air pollutant species concentrations with $\sim 5$ to 10 groups, also known as factors or components. Although PCA factors may be identifiable with emission sources in some applications, factors fundamentally represent correlations among species and potentially reflect a variety of aero- 
metric processes (e.g., secondary species formation, meteorological effects). In our application, we interpret PCA factors as associations among species that are indicative of variations in the chemical environment, and refer to such species associations as components for brevity. A related methodology, PMF (EPA, 2014), differs in part from PCA in that PMF constrains factors to positive values. This constraint is physically realistic if PCA factors are interpreted as unique emission source contributions. The negative values permitted by PCA are in fact meaningful and informative if, in addition to emissions, factors represent a larger suite of physical and chemical processes (e.g., deposition; chemical loss processes; contrasts between inland versus marine air mass transport) as well as species origins.

\subsubsection{Application}

We report two main versions of PCA, with additional versions used for sensitivity tests and auxiliary information. PCA1 is applied to measurements made at SEARCH sites from 2008 through 2013. The 23 gas and $\mathrm{PM}_{2.5}$ measurements comprise daily-average concentrations of $\mathrm{PM}_{2.5} \mathrm{EC}$ and OC (thermal-optical reflectance, TOR), daily averages of gases $\mathrm{NH}_{3}$ (measured continuously or at 24-hour resolution) and continuous $\mathrm{NO}_{x}$ and $\mathrm{NO}_{z}$, secondary species (daily peak $8 \mathrm{~h} \mathrm{O}$, plus $\mathrm{PM}_{2.5} \mathrm{SO}_{4}, \mathrm{NH}_{4}$, and $\mathrm{NO}_{3}$ ), and $\mathrm{PM}_{2.5}$ crustal elements (XRF measurements of $\mathrm{Al}, \mathrm{Si}$, and $\mathrm{Fe})$, species associated with salts $\left(\mathrm{PM}_{2.5} \mathrm{Na}, \mathrm{Cl}, \mathrm{Mg}\right.$, and $\mathrm{Ca}$ ions), and trace metals $\left(\mathrm{PM}_{2.5} \mathrm{Zn}, \mathrm{Cu}\right)$. Both daily averages and daily 1-hour maxima of gases $\left(\mathrm{CO}\right.$ and $\left.\mathrm{SO}_{2}\right)$ are included to match the temporal resolution of the other daily data while also potentially capturing shorter-duration plumes. Watersoluble $\mathrm{PM}_{2.5} \mathrm{~K}$ ( $\mathrm{K}$ ion) is included as a potential indicator of biomass combustion. Because some species used in PCA1 were not measured throughout the 15-year SEARCH program, PCA2 is carried out to interpret long-term OC trends from 1999 through 2013. PCA2 excludes measurements that commenced in 2008 (water-soluble $\mathrm{Ca}, \mathrm{Mg}, \mathrm{K}, \mathrm{Na}$, and $\mathrm{Cl}$ ). XRF $\mathrm{Ca}$ and nsK are used instead of water-soluble $\mathrm{Ca}$ and $\mathrm{K}$, respectively. Without $\mathrm{Na}$ and $\mathrm{Cl}$ in PCA2, salt is not detectable, as will be discussed. $\mathrm{NH}_{3}$ is excluded from PCA2, since those measurements began in 2004. Daily-average $\mathrm{O}_{3}$ is included in PCA2 to complement daily peak $8 \mathrm{~h} \mathrm{O}_{3}$.

The sensitivity of our results to the choice of statistical method is examined by comparing PCA1 and PCA2 and by using additional PCA and PMF applications. As described in Sect. 3.5.3, the range of results obtained from PCA1, PCA2, other PCAs, and PMF is used to estimate uncertainty. The additional PCA applications are carried out by using special data, different suites of measurements, or different measurement periods. Non-methane organic compound (NMOC) measurements made every day at JST from 1999 through 2008 are incorporated to generate PCA3 as a modification of PCA2 (no ions and only XRF elements, and shorter time period). Alternate versions of PCA2 are carried out for 2004
2013 CTR data to see if factor loadings are robust and relatively insensitive to the choice of seasonal indicators (PCA4 and PCA5). The EPA PMF model (version 5; EPA, 2014) was applied to the same CTR and JST measurements used in PCA2. PMF requires estimates of measurement uncertainty, which may be species-specific or even sample-specific. Two sets of uncertainty estimates were employed: uniform (10\% of species concentrations) (PMF1), and species-specific (incorporating detection limits and species uncertainties of 5 to $25 \%$ of measured concentrations) (PMF2).

For PCA applications, the daily OC concentrations at each site are apportioned using daily PCA factor scores. The OC apportionment is carried out by multiple regression of daily OC concentrations against daily factor scores, retaining those that are statistically significant $(p<0.05)$. Since the PCA components are orthogonal, the regression coefficients are more stable than would be the case for multiple regression against various tracer species, which are typically intercorrelated. The PMF model generates source contributions internally.

\subsubsection{PCA Components}

PCA1 and PCA2 reveal consistent sets of species associations, resulting in 6-8 principal components at each SEARCH site (Table 2). For clarity, we designate the components as (1) combustion, (2) crustal, (3) seasonal, (4) $\mathrm{SO}_{2}$, (5) $\mathrm{SO}_{4}$, (6) metals, (7) salt, and (8) other. These names are used as descriptors, rather than as designated emission sources. Component characteristics are discussed below. The full orthogonal solutions are shown in the Supplement (Tables S4 to S11). The values in Tables S4 to S11 are the coefficients of the linear combinations of standardized species concentrations (daily concentration less mean divided by standard deviation); each tabled value is also the correlation $(r)$ between a given species and a particular component. High $(\sim 1)$ or low $(\sim-1)$ values indicate high correlation or anticorrelation, respectively; both are meaningful. A value near zero indicates little or no correlation, so values in the range of $\sim-0.5$ to 0.5 represent associations ranging from moderate anti-correlation $(-0.5)$ to zero correlation to moderate correlation $(0.5)$.

The OC apportionments indicate statistically significant relationships between OC and four to seven PCA components (Tables S12 and S13). Mean contributions of each statistically significant component to daily $\mathrm{OC}$ at each site using both PCA1 and PCA2 are summarized in Table 3; these contributions are expressed as percentages of total $\mathrm{OC}$ in $\mathrm{Ta}-$ ble S14. PCA1 and PCA2 each indicate that OC is associated with multiple components at all sites. Except at YRK and OLF (PCA2 only), the overall OC associations are strongest for the combustion component (Tables S4 to S11). 
Table 2. Species associated with each PCA factor (component). Component names are keyed to the species. Three species are listed in decreasing order of association for associations of 0.6 or greater (or -0.6 or smaller). Negative values indicate anti-correlation. $\mathrm{CO}^{x}$ and $\mathrm{SO}_{2}^{x}$ are $1 \mathrm{~h}$ daily maximum $\mathrm{CO}$ and $\mathrm{SO}_{2}$, respectively. $\mathrm{O}_{3}^{x}$ is $8 \mathrm{~h}$ daily maximum $\mathrm{O}_{3}$. PCA1, 2008-2013; PCA2, 1999-2013. $N$ is number of days.

\begin{tabular}{|c|c|c|c|c|c|c|c|c|c|c|}
\hline PCA & Site & $N$ & Combustion & Crustal & Seasonal & $\mathrm{SO}_{2}$ & $\mathrm{SO}_{4}$ & Metals & Salt & Other \\
\hline 1 & BHM & 364 & $\mathrm{CO}, \mathrm{NO}_{x}, \mathrm{OC}$ & $\mathrm{Al}, \mathrm{Si}$ & $\mathrm{NO}_{3}$ & $\mathrm{SO}_{2}^{x}, \mathrm{SO}_{2}$ & $\mathrm{NH}_{4}, \mathrm{SO}_{4}$ & $\mathrm{Zn}, \mathrm{Cu}, \mathrm{Fe}$ & $\mathrm{K}$ & $\mathrm{NO}_{z}$ \\
\hline 1 & CTR & 383 & $\mathrm{EC}, \mathrm{OC}, \mathrm{CO}$ & $\mathrm{Si}, \mathrm{Fe}, \mathrm{Al}$ & $\mathrm{NH}_{3}$ & $\mathrm{SO}_{2}, \mathrm{SO}_{2}^{x}$ & $\mathrm{SO}_{4}, \mathrm{NH}_{4}$ & $\mathrm{Cu}, \mathrm{Zn}$ & $\mathrm{Na}, \mathrm{Cl}, \mathrm{Mg}$ & \\
\hline 1 & GFP & 100 & $\mathrm{CO}, \mathrm{CO}^{x}, \mathrm{NO}_{x}$ & $\mathrm{Si}, \mathrm{Fe}, \mathrm{Al}$ & $\mathrm{O}_{3}^{x}, \mathrm{NH}_{3}$ & $\mathrm{SO}_{2}, \mathrm{SO}_{2}^{x}$ & $\mathrm{NH}_{4}, \mathrm{SO}_{4}$ & & $\mathrm{Cl}, \mathrm{Na}, \mathrm{Mg}$ & $\mathrm{Ca}$ \\
\hline 1 & JST & 516 & $\mathrm{CO}, \mathrm{NO}_{x}, \mathrm{EC}$ & $\mathrm{Si}, \mathrm{Al}, \mathrm{Fe}$ & $\mathrm{O}_{3}^{x}, \mathrm{NH}_{3},-\mathrm{NO}_{3}$ & $\mathrm{SO}_{2}^{x}, \mathrm{SO}_{2}$ & $\mathrm{NH}_{4}, \mathrm{SO}_{4}$ & & $\mathrm{~K}, \mathrm{Cl}, \mathrm{Mg}$ & $\mathrm{Na}$ \\
\hline 1 & OAK & 100 & $\mathrm{CO}^{x}, \mathrm{CO}$ & $\mathrm{Fe}, \mathrm{Al}, \mathrm{Si}$ & $\mathrm{NH}_{3}, \mathrm{O}_{3}^{x}$ & $\mathrm{SO}_{2}^{x}, \mathrm{SO}_{2}$ & $\mathrm{SO}_{4}, \mathrm{NH}_{4}$ & $\mathrm{NO}_{x}, \mathrm{Cu}, \mathrm{NO}_{z}, \mathrm{Zn}$ & $\mathrm{Na}, \mathrm{Cl}, \mathrm{Mg}$ & \\
\hline 1 & OLF & 327 & $\mathrm{NO}_{x}, \mathrm{CO}, \mathrm{EC}$ & $\mathrm{Si}, \mathrm{Al}, \mathrm{Fe}$ & $\mathrm{NH}_{3}, \mathrm{O}_{3}^{x}$ & $\mathrm{SO}_{2}, \mathrm{SO}_{2}^{x}$ & $\mathrm{SO}_{4}, \mathrm{NH}_{4}$ & $\mathrm{Cu}$ & $\mathrm{Na}, \mathrm{Mg}, \mathrm{Cl}$ & \\
\hline 1 & PNS & 44 & $\mathrm{CO}, \mathrm{NO}_{x}, \mathrm{EC}$ & $\mathrm{Si}, \mathrm{Al}, \mathrm{Fe}$ & $\mathrm{O}_{3}^{x}$ & $\mathrm{SO}_{2}, \mathrm{SO}_{2}^{x}$ & $\mathrm{NH}_{4}, \mathrm{SO}_{4}$ & & $\mathrm{Na}, \mathrm{Mg}, \mathrm{Cl}$ & \\
\hline 1 & YRK & 426 & $\mathrm{NO}_{x}, \mathrm{NO}_{3}, \mathrm{CO}$ & $\mathrm{Si}, \mathrm{Fe}, \mathrm{Al}$ & $\mathrm{O}_{3}^{x}, \mathrm{OC}, \mathrm{EC}$ & $\mathrm{SO}_{2}^{x}, \mathrm{SO}_{2}$ & $\mathrm{SO}_{4}, \mathrm{NH}_{4}$ & $\mathrm{Cu}$ & $\mathrm{Na}, \mathrm{Cl}, \mathrm{Mg}$ & $\mathrm{Zn}$ \\
\hline 2 & BHM & 1513 & $\mathrm{CO}, \mathrm{CO}^{x}, \mathrm{NO}_{x}$ & $\mathrm{Al}, \mathrm{Si}$ & $\mathrm{O}_{3}, \mathrm{O}_{3}^{x},-\mathrm{NO}_{3}$ & $\mathrm{SO}_{2}^{x}, \mathrm{SO}_{2}$ & $\mathrm{NH}_{4}, \mathrm{SO}_{4}$ & $\mathrm{Zn}, \mathrm{Cu}, \mathrm{Fe}$ & & \\
\hline 2 & CTR & 1258 & $\mathrm{OC}, \mathrm{EC}, \mathrm{CO}^{x}$ & $\mathrm{Si}, \mathrm{Fe}, \mathrm{Al}$ & $\mathrm{O}_{3}^{x}, \mathrm{O}_{3}$ & $\mathrm{SO}_{2}, \mathrm{NO}_{x}, \mathrm{SO}_{2}^{x}$ & $\mathrm{SO}_{4}, \mathrm{NH}_{4}$ & $\mathrm{Cu}$ & & \\
\hline 2 & GFP & 376 & $\mathrm{CO}^{x}, \mathrm{CO}, \mathrm{NO}_{x}$ & $\mathrm{Si}, \mathrm{Fe}, \mathrm{Al}$ & $\mathrm{O}_{3}, \mathrm{O}_{3}^{x}$ & $\mathrm{SO}_{2}^{x}, \mathrm{SO}_{2}$ & $\mathrm{NH}_{4}, \mathrm{SO}_{4}$ & $\mathrm{Cu}, \mathrm{Zn}$ & & \\
\hline 2 & JST & 2593 & $\mathrm{CO}, \mathrm{CO}^{x}, \mathrm{NO}_{x}$ & $\mathrm{Si}, \mathrm{Al}, \mathrm{Fe}$ & $\mathrm{NO}_{3},-\mathrm{O}_{3}^{x},-\mathrm{O}_{3}$ & $\mathrm{SO}_{2}^{x}, \mathrm{SO}_{2}$ & $\mathrm{NH}_{4}, \mathrm{SO}_{4}, \mathrm{O}_{3}^{x}$ & $\mathrm{Cu}$ & & \\
\hline 2 & OAK & 707 & $\mathrm{CO}^{x}, \mathrm{CO}, \mathrm{EC}$ & $\mathrm{Si}, \mathrm{Fe}, \mathrm{Al}$ & $\mathrm{O}_{3}, \mathrm{O}_{3}^{x}$ & $\mathrm{SO}_{2}^{x}, \mathrm{SO}_{2}$ & $\mathrm{SO}_{4}, \mathrm{NH}_{4}$ & $\mathrm{Cu}, \mathrm{Zn}$ & & \\
\hline 2 & OLF & 948 & $\mathrm{CO}^{x}, \mathrm{CO}, \mathrm{NO}_{x}$ & $\mathrm{Si}, \mathrm{Fe}, \mathrm{Al}$ & $\mathrm{O}_{3}, \mathrm{O}_{3}^{3}$ & $\mathrm{SO}_{2}^{x}, \mathrm{SO}_{2}$ & $\mathrm{NH}_{4}, \mathrm{SO}_{4}, \mathrm{NO}_{z}$ & $\mathrm{Zn}, \mathrm{Cu}$ & & \\
\hline 2 & PNS & 445 & $\mathrm{EC}, \mathrm{CO}, \mathrm{NO}_{x}$ & $\mathrm{Si}, \mathrm{Al}, \mathrm{Fe}$ & $\mathrm{O}_{3}^{x}, \mathrm{O}_{3}, \mathrm{SO}_{4}, \mathrm{NH}_{4}$ & $\mathrm{SO}_{2}^{x}, \mathrm{SO}_{2}$ & & $\mathrm{Cu}$ & & $\mathrm{NO}_{z}$ \\
\hline 2 & YRK & 1435 & $\mathrm{CO}^{x}, \mathrm{NO}_{x}, \mathrm{NO}_{3}$ & $\mathrm{Si}, \mathrm{Fe}, \mathrm{Al}$ & $\mathrm{O}_{3}^{x}, \mathrm{SO}_{4}, \mathrm{O}_{3}, \mathrm{NH}_{4}$ & $\mathrm{SO}_{2}^{x}, \mathrm{SO}_{2}$ & & $\mathrm{Cu}$ & & $\mathrm{Zn}$ \\
\hline
\end{tabular}

Table 3. Mean OC concentrations associated with components identified by PCA1 (2008-2013) and PCA2 (1999-2013). NS is not statistically significant, $\mathrm{n} / \mathrm{a}$ is not applicable (component not present in PCA). Units are $\mu \mathrm{g} \mathrm{m}^{-3}$. Standard errors of the means ranged from 0.003 to $0.09 \mu \mathrm{g} \mathrm{m}^{-3}$ (up to $0.25 \mu \mathrm{g} \mathrm{m}^{-3}$ for PNS PCA1).

\begin{tabular}{llrrrrrrrrr}
\hline PCA & Site & $N$ & Combustion & Crustal & Seasonal & $\mathrm{SO}_{2}$ & $\mathrm{SO}_{4}$ & Metals & Salt & Other \\
\hline 1 & BHM & 364 & 1.36 & 0.09 & 0.40 & 0.35 & 0.45 & 0.15 & 0.14 & 0.10 \\
1 & CTR & 383 & 1.28 & 0.26 & 0.56 & $\mathrm{NS}$ & 0.33 & $\mathrm{NS}$ & $\mathrm{NS}$ & $\mathrm{n} / \mathrm{a}$ \\
1 & GFP & 100 & 0.95 & $\mathrm{NS}$ & 0.45 & 0.15 & 0.25 & $\mathrm{NS}$ & -0.41 & 0.62 \\
1 & JST & 516 & 1.09 & 0.16 & 0.49 & 0.07 & 0.27 & $\mathrm{n} / \mathrm{a}$ & 0.64 & 0.11 \\
1 & OAK & 100 & 0.40 & $\mathrm{NS}$ & 0.50 & 0.37 & 0.53 & 0.32 & -0.27 & $\mathrm{n} / \mathrm{a}$ \\
1 & OLF & 327 & 0.74 & $-0.08^{\mathrm{a}}$ & 0.52 & 0.16 & 0.27 & $\mathrm{NS}$ & $-0.09^{\mathrm{a}}$ & $\mathrm{n} / \mathrm{a}$ \\
1 & PNS & 44 & 1.95 & $\mathrm{NS}$ & 0.33 & $\mathrm{NS}$ & 0.56 & $\mathrm{n} / \mathrm{a}$ & -0.63 & $\mathrm{n} / \mathrm{a}$ \\
1 & YRK & 426 & 0.14 & 0.14 & 1.09 & $\mathrm{NS}$ & 0.26 & 0.16 & 0.15 & 0.47 \\
\hline 2 & BHM & 1513 & 1.60 & 0.19 & 0.47 & 0.38 & 0.57 & 0.48 & $\mathrm{n} / \mathrm{a}$ & $\mathrm{n} / \mathrm{a}$ \\
2 & CTR & 1258 & 1.50 & 0.12 & 0.69 & $\mathrm{NS}$ & 0.66 & $\mathrm{NS}$ & $\mathrm{n} / \mathrm{a}$ & $\mathrm{n} / \mathrm{a}$ \\
2 & GFP & 376 & 0.72 & 0.14 & 0.37 & 0.21 & 0.50 & 0.25 & $\mathrm{n} / \mathrm{a}$ & $\mathrm{n} / \mathrm{a}$ \\
2 & JST & 2593 & 2.58 & 0.32 & $0.06^{\mathrm{b}}$ & $\mathrm{NS}$ & $1.01^{\mathrm{b}}$ & 0.13 & $\mathrm{n} / \mathrm{a}$ & $\mathrm{n} / \mathrm{a}$ \\
2 & OAK & 707 & 1.50 & $\mathrm{NS}$ & 0.47 & $\mathrm{NS}$ & 0.59 & $\mathrm{NS}$ & $\mathrm{n} / \mathrm{a}$ & $\mathrm{n} / \mathrm{a}$ \\
2 & OLF & 948 & 0.81 & $-0.06^{\mathrm{a}}$ & 0.25 & 0.09 & 1.02 & 0.20 & $\mathrm{n} / \mathrm{a}$ & $\mathrm{n} / \mathrm{a}$ \\
2 & PNS & 445 & 1.55 & $\mathrm{NS}$ & $0.45^{\mathrm{c}}$ & 0.17 & $\mathrm{n} / \mathrm{a}$ & $\mathrm{NS}$ & $\mathrm{n} / \mathrm{a}$ & 0.36 \\
2 & YRK & 1435 & 0.76 & 0.20 & $1.40^{\mathrm{c}}$ & 0.05 & $\mathrm{n} / \mathrm{a}$ & 0.39 & $\mathrm{n} / \mathrm{a}$ & 0.29 \\
\hline
\end{tabular}

a OLF PCA1 and PCA2 crustal and PCA1 salt OC mean concentrations are negative due to inverse associations of OC with crustal and salt

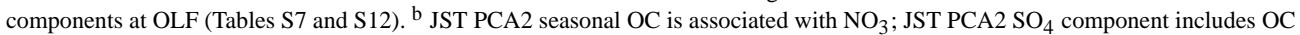
associated with $\mathrm{O}_{3}$ (Table 2). ${ }^{\mathrm{c}}$ PNS and YRK PCA2 seasonal components include OC associated with $\mathrm{SO}_{4}$ (Table 2).

The PMF source profiles varied depending on the choice of uncertainty inputs, but yielded average OC apportionments that were qualitatively comparable to PCA2 (Fig. S15). The $\mathrm{PMF}$ crustal $\mathrm{OC}$ and $\mathrm{SO}_{4}$-associated $\mathrm{OC}$ concentrations were comparable to PCA (Fig. S16). However, PMF source profiles combined $\mathrm{CO}$ and $\mathrm{O}_{3}$, whereas PCA tended to separate $\mathrm{O}_{3}$ from $\mathrm{CO}$, leading to differences in the apportionment of $\mathrm{OC}$ to combustion and seasonal components (Fig. S16). Differences between PCA and PMF occur in part because the PCA seasonal component generally comprised contrasts (e.g., positive $\mathrm{O}_{3}$, negative inorganic particulate $\mathrm{NO}_{3}$ ) whereas PMF forced positive solutions. In these applications, PCA predicted high OC concentrations more accurately than PMF did (Fig. S17). 


\section{Combustion}

All sites exhibit a suite of species associated with combustion processes $\left(\mathrm{EC}, \mathrm{OC}, \mathrm{CO}, \mathrm{Kbb}\right.$ or $\mathrm{K}$ ion, $\mathrm{NO}_{x}$ or $\mathrm{NO}_{z}$ ). The variations in combustion associations among sites suggest different source mixes, differences in air mass ages (e.g., fresh emissions at urban sites, more aged emissions at rural sites), or differing transport of polluted air masses. For example, $\mathrm{NO}_{z}$ is more strongly associated than $\mathrm{NO}_{x}$ with the combustion component at the two most rural sites, CTR and OAK. OC associated with the combustion factor could therefore comprise material that would be classified as either POA or SOA by other analytical approaches (e.g., hydrocarbonlike OA (HOA) or more-oxidized OA (MO-OOA) by AMS).

Mean combustion OC ranges from 0.7 to $1.6 \mathrm{\mu g} \mathrm{m}^{-3}$ for PCA1 (2008-2013) and from 1.5 to $2.6 \mu \mathrm{g} \mathrm{m}^{-3}$ for PCA2 (1999-2013), except at YRK (Table 3). Daily PCA1 and PCA2 combustion OC concentrations are correlated at all sites (Fig. S18). Mean absolute differences between PCA1 and PCA2 computed combustion OC range from 0.1 to $0.7 \mu \mathrm{g} \mathrm{m}^{-3}$ (not tabled). However, the mean PCA1 and PCA2 combustion OC concentrations are averaged over different time periods, so the differences in their averages are partly due to declining $\mathrm{EC}, \mathrm{CO}$, and $\mathrm{NO}_{x}$ concentrations (Table 1). Trends in OC components are discussed in Sect. 3.4.4. Mean PCA 2 combustion OC ranged from 25 to $63 \%$ of mean OC concentrations (Table 3).

Various combustion processes are expected to influence individual SEARCH sites to different degrees. CTR OCbb correlates significantly $(p<0.0001)$ with PCA1 and PCA2 combustion-associated $\mathrm{OC}\left(r^{2}=0.54\right.$ and 0.58 , respectively, Fig. S19a), suggesting that the combustion component at CTR is primarily associated with biomass burning. Whereas OCbb is computed from Kbb (Sect. 3.4), PCA1 and PCA2 combustion $\mathrm{OC}$ concentrations are determined from the principal component association of $\mathrm{CO}, \mathrm{EC}$, and either $\mathrm{K}$ ion (PCA1) or Kbb (PCA2) (Table S5). The association of K ion and $\mathrm{Kbb}$ with $\mathrm{CO}$ and $\mathrm{EC}$ at CTR links potassium with a combustion process. At BHM and JST, multiple regression of combustion OC against NO, gas-phase organic species (Blanchard et al., 2010), and non-polar OC compounds (including polycyclic aromatic hydrocarbons, PAHs, and iso/anteisoalkanes, or hopanes and steranes) (Blanchard et al., 2014a) indicates an association of fresh emissions (NO) and non-oxidized organic compounds with PCA combustion OC (Fig. S19b). The urban PCA combustion factor associates $\mathrm{CO}, \mathrm{EC}$, and daily-average $\mathrm{NO}_{x} ; 1 \mathrm{~h}$ maximum NO and non-oxidized organic compound concentrations were not used in determining either PCA1 or PCA2 (Tables S4 and S7). Urban PCA combustion OC is more likely attributable primarily to motor vehicle exhaust emissions than to biomass burning.

\section{Crustal}

A crustal component is present at all sites, associated with $\mathrm{Al}$, $\mathrm{Si}, \mathrm{Fe}$, and, to varying degrees, $\mathrm{Ca}$. At $\mathrm{BHM}, \mathrm{Fe}$ associates more prominently with a metals component, consistent with previous studies indicating the impact of industrial facilities (including metals fabrication) on $\mathrm{PM}_{2.5}$ at $\mathrm{BHM}$ (Baumann et al., 2008; Blanchard et al., 2014b).

The mean crustal-associated OC concentrations vary from 0.1 to $0.3 \mu \mathrm{g} \mathrm{m}^{-3}$ at inland sites (Table 3). Coastal sites exhibit non-significant, minor, or inverse associations of OC with crustal elements ( -0.1 to $0.1 \mu \mathrm{g} \mathrm{m}^{-3}$, Table 3$)$. Inverse associations indicate that $\mathrm{OC}$ concentrations at coastal sites are lower than average when $\mathrm{Al}, \mathrm{Si}$, and $\mathrm{Fe}$ concentrations are elevated. PCA1 and PCA2 crustal OC concentrations correlate (Fig. S20) and crustal OC correlates with Si (Fig. S21). Crustal-associated OC could derive from regionwide phenomena (e.g., transport of Saharan dust), but may also stem from ubiquitous and widely distributed activities that suspend crustal material. Potential sources include soilderived OC (e.g., agricultural activities, construction, or road dust), or biomass burning that lofts crustal material (e.g., through plowing material into debris piles). Road dust is known to include OC among its constituents (e.g., McDonald et al., 2013). There are two episodes with high crustal OC at CTR during June 2013. Elevated concentrations of $\mathrm{Al}, \mathrm{Si}$, and Fe co-occurred at all SEARCH sites during 9-13 and 23-28 June 2013, thus suggesting region-wide events. Back-trajectory calculations indicate southerly air flow during these times. Trajectories arrived at CTR and JST after $\sim 24 \mathrm{~h}$ overland transport from the Gulf coast, whereas trajectories arrived at OLF from overwater transport. At other times, elevated concentrations of crustal elements occur at single sites, indicating more local events.

\section{Seasonal}

A seasonal component is present at all sites, but in two forms: positive $\mathrm{O}_{3}$ and $\mathrm{NH}_{3}$ (if measured), along with negative inorganic particulate $\mathrm{NO}_{3}$, at BHM PCA2, CTR, GFP, JST PCA1, OAK, OLF, PNS, and YRK, or with reverse signs (e.g., relatively weak negative $\mathrm{O}_{3}$ ) at BHM PCA1 and JST PCA2. As noted, sign reversals represent a change in coordinate directions and need not have physical significance; however, the association of $\mathrm{OC}$ with the seasonal component may differ depending on sign (discussed below). We denote this component seasonal rather than photochemical. While this factor has photochemical properties, it is comprised of species with seasonality variations that result from multiple processes: emissions $\left(\mathrm{NH}_{3}\right)$, photochemistry $\left(\mathrm{O}_{3}\right)$, and temperature- and $\mathrm{RH}$-sensitive thermodynamic equilibrium (inorganic particulate $\mathrm{NO}_{3}$ ). The seasonal component evidently represents seasonal variations not otherwise described by the seasonal variations of the crustal, $\mathrm{SO}_{4}$, and other components. Because of the strong connection of the 
seasonal component to $\mathrm{O}_{3}$, seasonal $\mathrm{OC}$ is plausibly related to the less-oxidized oxygenated organic aerosol (LO-OOA) component reported by Xu et al. (2015a, b). LO-OOA exhibits a strong diurnal pattern, with night maxima and day minima (Xu et al., 2015a, b). However, the LO-OOA diurnal variation is opposite to $\mathrm{O}_{3}$ diurnal variations, which exhibit daytime maxima. Since PCA was applied to daily-resolution data, it is not possible to directly compare the PCA seasonal OC to time-resolved LO-OOA. We note that meteorological conditions that result in high peak daily $\mathrm{O}_{3}$ concentrations (with higher seasonal OC concentrations) are also conducive to nitrate radical formation, which exhibits nighttime maxima and is associated with LO-OOA (Xu et al., 2015a, b). Further comparisons are provided in Sect. 3.5.3.

The mean PCA1 seasonal-component OC (OC associated with higher $\mathrm{O}_{3}$, higher $\mathrm{NH}_{3}$, lower $\mathrm{NO}_{x}$, or lower $\mathrm{PM}_{2.5}$ inorganic $\mathrm{NO}_{3}$ ) ranges from 0.4 to $0.6 \mu \mathrm{g} \mathrm{m}^{-3}$ at all sites (e.g., $23 \%$ of OC at CTR, $13 \%$ at BHM and JST, $28 \%$ at OLF), except at YRK where the average is $1.0 \mu \mathrm{g} \mathrm{m}^{-3}$. The positive association with $\mathrm{O}_{3}$ suggests that this $\mathrm{OC}$ component represents SOA formation from either or both anthropogenic and biogenic precursors. PCA2 seasonal OC correlates with PCA1 seasonal OC, except at JST. The JST PCA2 seasonal OC shows an inverse correlation (Fig. S22), indicating that the seasonal component represents higher winter (lower $\mathrm{O}_{3}$, higher $\mathrm{NO}_{3}$ ) OC concentrations, possibly pointing to an influence from domestic wood combustion for heating. The positive association of $\mathrm{OC}$ with $\mathrm{O}_{3}$ is quantified within the JST PCA2 $\mathrm{SO}_{4}$ component. The mean absolute differences between PCA1 and PCA2 seasonal-component OC concentrations range from 0.2 to $0.5 \mu \mathrm{g} \mathrm{m}^{-3}$.

\section{Sulfate}

$\mathrm{SO}_{4}$ and $\mathrm{NH}_{4}$ are always associated and usually represented by a single component, denoted $\mathrm{SO}_{4}$. However, $\mathrm{SO}_{4}$ and $\mathrm{NH}_{4}$ are part of the seasonal component for PNS and YRK PCA2, suggesting that differentiation of the $\mathrm{SO}_{4}$ and seasonal components is subject to uncertainty. $\mathrm{O}_{3}$ is associated with both seasonal and $\mathrm{SO}_{4}$ components.

All SEARCH sites show an association of OC with $\mathrm{SO}_{4}$ ranging from 0.3 to $0.6 \mu \mathrm{g} \mathrm{m}^{-3}$ on average for PCA1 and from 0.5 to $1.0 \mu \mathrm{g} \mathrm{m}^{-3}$ on average for PCA2 (Table 3), with PCA2 $\mathrm{SO}_{4}$ OC representing 15 to $44 \%$ of the 1999-2013 mean OC concentrations (15\% at BHM; 22-25\% at CTR, GFP, JST, and OAK; $44 \%$ at OLF). Mean PCA1 associations of OC with $\mathrm{SO}_{4}$ were $14 \%$ of OC at CTR, $15 \%$ at BHM, $18 \%$ at OLF, $10 \%$ at JST, and $11 \%$ at YRK. PCA1 and PCA2 $\mathrm{SO}_{4} \mathrm{OC}$ concentrations are correlated (Fig. S23) with mean absolute differences in PCA1 and PCA2 $\mathrm{SO}_{4}$ associated OC concentrations of 0.2 to $0.5 \mu \mathrm{g} \mathrm{m}^{-3}$; PCA2 did not separate the seasonal and $\mathrm{SO}_{4}$ components at PNS and YRK (Tables S10 and S11). The mass of OC associated with $\mathrm{SO}_{4}$ averages 20 to $30 \%$ of the $\mathrm{SO}_{4}$ concentrations (Fig. S24); therefore, that $\mathrm{SO}_{4}$-associated OC concen- trations decline over time along with decreasing $\mathrm{SO}_{4}$ concentrations. The presence and relative importance of $\mathrm{SO}_{4}$ associated $\mathrm{OC}$ is consistent with research indicating the role of $\mathrm{SO}_{4}$ in transferring isoprene gas-phase reaction products to the condensed phase (e.g., Surratt et al., 2007; Xu et al., $2015 \mathrm{a}, \mathrm{b})$. Seasonal variations, discussed below, also support biogenic origins of $\mathrm{SO}_{4}-\mathrm{OC}$. The quantitative relationship of our $\mathrm{SO}_{4}$-associated $\mathrm{OC}$ factor to $\mathrm{SO}_{4}$ is the same as the relationship between isoprene $\mathrm{OA}$ and $\mathrm{SO}_{4}$, which $\mathrm{Xu}$ et al. $(2015 \mathrm{a}, \mathrm{b})$ reported as $0.42 \mu \mathrm{g} \mathrm{m}^{-3}$ isoprene OA per $1 \mu \mathrm{g} \mathrm{m}^{-3} \mathrm{SO}_{4}$. Based on their reported $\mathrm{OM} / \mathrm{OC}$ for isoprene OA (1.97), their result is $0.21 \mu \mathrm{g} \mathrm{m}^{-3}$ isoprene OC per $1 \mu \mathrm{g} \mathrm{m}^{-3} \mathrm{SO}_{4}$. For CTR (2008-2013, $n=383$ days), we obtain $0.216( \pm 0.008,1 \mathrm{SE}) \mu \mathrm{g} \mathrm{m}{ }^{-3} \mathrm{SO}_{4}$-associated OC per $1 \mu \mathrm{g} \mathrm{m}^{-3} \mathrm{SO}_{4}$ (PCA1), 0.190 ( $\left.\pm 0.004,1 \mathrm{SE}\right) \mu \mathrm{g} \mathrm{m}{ }^{-3} \mathrm{SO}_{4-}$ associated OC per $1 \mu \mathrm{g} \mathrm{m}^{-3} \mathrm{SO}_{4}$ (PCA2), $0.213( \pm 0.003$, $1 \mathrm{SE}) \mu \mathrm{g} \mathrm{m}^{-3} \mathrm{SO}_{4}$-associated OC per $1 \mu \mathrm{g} \mathrm{m}^{-3} \mathrm{SO}_{4}$ (PMF1), and $0.211( \pm 0.001,1 \mathrm{SE}) \mu \mathrm{g} \mathrm{m}{ }^{-3} \mathrm{SO}_{4}$-associated $\mathrm{OC}$ per $1 \mu \mathrm{g} \mathrm{m}^{-3} \mathrm{SO}_{4}$ (PMF2).

\section{$\mathrm{SO}_{2}$}

The $\mathrm{SO}_{2}$ component, present at all sites, identifies influences of relatively fresh plumes, whether from electric generating units (EGUs), industrial, or other $\mathrm{SO}_{2}$ sources. At CTR, $\mathrm{NO}_{x}$ is more strongly associated with the $\mathrm{SO}_{2}$ component than with the combustion component, consistent with relatively less aged plumes and more aged general combustion influence. Differences between urban and rural sites are evident; for example, OC at CTR and YRK is not significantly related to the $\mathrm{SO}_{2}$ factors, but $\mathrm{OC}$ is related to the $\mathrm{SO}_{2}$ factors at urban sites. This difference indicates the influence of $\mathrm{SO}_{2}$ emission sources within urban areas, consistent with visual observations and measurements made near emission sources in Birmingham (Blanchard et al., 2014b).

$\mathrm{OC}$ associated with $\mathrm{SO}_{2}$, indicative of fresh emissions, accounted for 0.07 to $0.37 \mu \mathrm{g} \mathrm{m}^{-3}$ on average (12\% of OC at BHM, $2 \%$ at JST, $7 \%$ at GFP, $20 \%$ at OAK, and $10 \%$ at OLF, none at other sites using PCA1) (Tables 3 and $\mathrm{S} 14)$. PCA1 and PCA2 $\mathrm{SO}_{2} \mathrm{OC}$ concentrations are correlated (Fig. S25).

\section{Salt}

A salt (or salt-like) component (of marine or other origins) is evidenced by $\mathrm{Na}, \mathrm{Cl}$, and $\mathrm{Mg}$ in PCA1. Na appears as a separate other component for JST PCA1, suggesting multiple urban sources of one or more of these species, while JST PCA1 salt is defined by $\mathrm{K}, \mathrm{Cl}$, and $\mathrm{Mg}$. These species are not necessarily unique marine tracers; for example, various combustion processes generate $\mathrm{Cl}$ emissions.

Coastal sites show an inverse association of $\mathrm{OC}$ with $\mathrm{Na}$ and $\mathrm{Cl}$ (sea salt) (Table S14) and a negative mean OC contribution from salt (Table 3). We interpret this result as evidence that $\mathrm{OC}$ concentrations are lower at coastal sites when marine 
salt species concentrations are higher (i.e., anti-correlated), indicating that marine air masses are not an important source of OC. In contrast, mean salt-associated OC ranges from 0.14 to $0.15 \mu \mathrm{g} \mathrm{m}^{-3}$ (BHM and YRK) to $0.64 \mu \mathrm{g} \mathrm{m}^{-3}$ (JST). The species associations for the BHM and JST salt components suggest urban influences precluding identification of the salt component with marine air masses. Because $\mathrm{K}$ is associated with the JST salt component (and not with the JST combustion component) and $\mathrm{Na}$ is associated with the JST other component, it is possible that JST salt OC represents biomass combustion, while the JST combustion component primarily represents motor vehicle exhaust.

\section{Metals}

$\mathrm{Cu}$ and $\mathrm{Zn}$ appear on a metals component at six sites - BHM, CTR, GFP (PCA2), JST (PCA2), OAK, and OLF (PCA2); otherwise, $\mathrm{Cu}$ and $\mathrm{Zn}$ are associated with combustion or are split between the metals and other components. The $\mathrm{Cu}$ and $\mathrm{Zn}$ correlations range from $r=0.1$ to 0.3 in the full 1999 to 2013 data set, which does not suggest a simple or strong association between these two species. At JST, Cu correlates with $\mathrm{Pb}$.

\section{Other}

A component designated as other is present for BHM PCA1, GFP PCA1, JST PCA1, PNS PCA2, and YRK PCA1 and PCA2, indicating variability at urban and near-urban (YRK) sites not otherwise represented by the major components (Table 2).

\subsubsection{Intercomparisons and uncertainty}

For PCA3 (Table S15), the sum of alkanes, sum of aromatics, and $\alpha$-pinene are associated with the combustion component, whereas isoprene is associated predominantly with the $\mathrm{SO}_{4}$ component. The measured alkane and aromatic species are known constituents of motor vehicle exhaust (Blanchard et al., 2010), consistent with a mobile source contribution to the JST combustion component. Correlations between $\alpha$-pinene and $\mathrm{CO}, \mathrm{EC}$, and $\mathrm{NO}_{x}$ range from $r=0.5$ to 0.6 , mathematically associating these species, but the physical processes underlying the correlation are ambiguous (e.g., seasonal or meteorological versus common source emissions). Isoprene and pinenes can be factors in $\mathrm{O}_{3}$ formation, and the association of isoprene with $\mathrm{SO}_{4}$ could arise from a common seasonality or from atmospheric chemical processes generating SOA from isoprene (Surratt et al., 2007; Xu et al., 2015a, b). Additional work is needed to more fully interpret VOC species associations.

PCA4 and PCA5 yield consistent results when $\mathrm{NH}_{3}$ or daily-average $\mathrm{O}_{3}$ are either included or excluded from the analysis (Table S16).

The ranges of mean OC concentrations associated with each PCA component as obtained from the various applica- tions are listed for CTR, JST, and YRK in Table 4. Uncertainties in the mean OC concentrations associated with each PCA component are estimated as one-half the ranges for CTR and JST (comprising both PCA and PMF applications) and the full ranges for YRK (PCA applications only), which generally yield comparable uncertainties.

A summary of our PCA1 results compared to the 20122013 source apportionments reported by Xu et al. (2015a, b) is shown in Tables S17 through S19. For these comparisons, we determined the PCA1 means by matching days to each of the Xu et al. (2015a, b) multi-week study periods. The PCA1 combustion OC tends to compare in magnitude to AMS HOA, biomass burning OA (BBOA), cooking OA (COA) (when one or more such factors are found) or to MOOOA. The last correspondence would be expected to the extent that MO-OOA includes oxidized motor vehicle exhaust, other anthropogenic combustion emissions, or biomass burning (Xu et al., 2015a, b). As previously noted for CTR, PCA $\mathrm{SO}_{4}$-associated $\mathrm{OC}$ concentrations and AMS isoprene OA concentrations exhibit nearly identical regression relationships with $\mathrm{SO}_{4}$ concentrations. Some differences between mean PCA SO 4 -associated OC and mean AMS isoprene OA (converted to $\mathrm{OC}$ ) percentage apportionments are evident in Tables S17 through S19, however. Such differences appear to result from ambiguities in linking PCA elements with AMS designations, different numbers of factors (affecting the percentages), and differences in mean observed OA (OC) concentrations. The SEARCH and AMS mean OC concentrations are comparable for the CTR (SOAS) and YRK (winter) data. For JST (summer), JST (winter), and YRK (summer), the mean AMS OC concentrations exceed the mean SEARCH OC concentrations by 40,49 , and $85 \%$, respectively. The reasons for these differences are unknown, but operationally could be related to sampling and analytical methods. The SEARCH mean OC concentrations during the multi-week comparison periods are consistent with longerterm averages from 2012, 2013, and 2008-2013 (Tables S17S19). Since SEARCH reports $\mathrm{PM}_{2.5}$ size fractions and AMS is based on $\mathrm{PM}_{1}$ size fractions, higher AMS PM mass concentrations are not expected. No AMS component appears to correspond to the PCA crustal OC, which could relate to the difference in size fractions sampled. The PCA crustal OC concentrations are generally small except during occasional events, as previously noted.

Comparisons of our results to results reported by Kleindienst et al. (2010) are shown in Fig. S26. Kleindienst et al. (2010) determined organic tracer concentrations on archived samples from the SEARCH Carbonaceous Aerosol Characterization Experiment (CACHE) archive. Twenty samples were analyzed, five each from BHM, CTR, JST, and PNS, collected during May $(7,13,22,28)$ and August (17) 2005 (Kleindienst et al., 2010). SEARCH OC measurements are made on filters from a sampler with a denuder placed upstream to remove organic gases, whereas the CACHE sampler was not denuded. The CACHE OC 
Table 4. Ranges of mean OC concentrations associated with each PCA component. The time period is 2009-2013. For each site, multiple methods were compared using a common set of days. For CTR (six methods), both the standard deviation and one-half the range of component mean concentrations are shown. For JST (three methods), one-half the range of component mean concentrations is shown. For YRK (two PCA methods), ranges are shown. YRK ranges are smaller than ranges for CTR and JST because no PMF analyses were carried out for YRK. The larger ranges for CTR and JST compared with YRK reflect the larger differences between PCA and PMF.

\begin{tabular}{|c|c|c|c|c|c|c|c|c|}
\hline \multirow[b]{2}{*}{ Component } & \multicolumn{4}{|c|}{$\mathrm{CTR}^{\mathrm{a}}$} & \multicolumn{2}{|c|}{$\mathrm{JST}^{\mathrm{b}}$} & \multicolumn{2}{|c|}{$\mathrm{YRK}^{\mathrm{c}}$} \\
\hline & $\begin{array}{r}\text { Range/2 } \\
\left(\mu \mathrm{g} \mathrm{m}^{-3}\right)\end{array}$ & $\begin{array}{r}\text { Range } / 2 \\
(\% \text { of mean })\end{array}$ & $\begin{array}{r}\text { SD } \\
\left(\mu \mathrm{g} \mathrm{m}^{-3}\right)\end{array}$ & $\begin{array}{r}\mathrm{SD} \\
(\% \text { of mean })\end{array}$ & $\begin{array}{r}\text { Range/2 } \\
\left(\mu \mathrm{g} \mathrm{m}^{-3}\right)\end{array}$ & $\begin{array}{r}\text { Range } / 2 \\
(\% \text { of mean })\end{array}$ & $\begin{array}{r}\text { Range } \\
\left(\mu \mathrm{g} \mathrm{m}^{-3}\right)\end{array}$ & $\begin{array}{r}\text { Range } \\
(\% \text { of mean })\end{array}$ \\
\hline Combustion & 0.44 & 18 & 0.30 & 12 & 0.34 & 12 & 0.34 & 14 \\
\hline Crustal & 0.09 & 4 & 0.07 & 3 & 0.11 & 4 & 0.09 & 4 \\
\hline Sulfate & 0.15 & 6 & 0.11 & 4 & 0.19 & 7 & 0.26 & 11 \\
\hline Seasonal & 0.36 & 15 & 0.25 & 10 & 0.43 & 15 & 0.12 & 5 \\
\hline $\mathrm{SO}_{2}$ & & & & & 0.03 & 1 & 0.03 & 1 \\
\hline Metals & & & & & 0.07 & 2 & 0.04 & 2 \\
\hline Salt & & & & & 0.33 & 12 & 0.16 & 7 \\
\hline Other & & & & & 0.05 & 2 & 0.16 & 7 \\
\hline
\end{tabular}

${ }^{\mathrm{a}}$ Mean $\mathrm{OC}=2.43 \mu \mathrm{g} \mathrm{m}^{-3}, n=383$ days, number of methods $=6(4 \mathrm{PCA}, 2 \mathrm{PMF}){ }^{\mathrm{b}}$ Mean OC $=2.85 \mu \mathrm{g} \mathrm{m}{ }^{-3}, n=398$ days, number of methods $=3(2 \mathrm{PCA}, 1 \mathrm{PMF}) .{ }^{\mathrm{c}}$ Mean $\mathrm{OC}=2.40 \mu \mathrm{g} \mathrm{m}^{-3}, n=426$ days, number of methods $=2(2 \mathrm{PCA})$.

concentrations were $\sim 50-100 \%$ higher than the SEARCH OC concentrations (Fig. S26), with a CACHE average OC concentration of $7.32 \mu \mathrm{g} \mathrm{m}^{-3}$ compared with SEARCH OC average of $4.62 \mu \mathrm{g} \mathrm{m}^{-3}$ when restricted to the 17 samples that had both CACHE and SEARCH OC concentrations. Kleindienst et al. (2010) accounted for $\sim 70 \%$ of the measured CACHE OC concentration using 11 source types, so their apportioned OC concentrations are roughly comparable to measured SEARCH OC concentrations. The sum of the Kleindienst et al. (2010) diesel and wood-burning OC concentrations correlates highly $\left(r^{2}=0.83\right)$ and agrees in magnitude (intercept $=0$; slope $=1$ ) with PCA2 combustion OC (Fig. S26). Wood-burning OC concentrations also correlate highly $\left(r^{2}=0.76\right)$ with PCA2 combustion OC, corresponding to $\sim 50-70 \%$ of the combustion OC concentrations (Fig. S26). OCbb (Sect. 3.4) correlates less well $\left(r^{2}=0.38\right)$ with wood-burning OC, and OCbb concentrations average $\sim 30 \%$ higher than wood-burning OC concentrations (Fig. S26). As previously noted, the fixed scaling factor used for estimating OCbb from Kbb does not reflect the variability among source types in $\mathrm{OCbb} / \mathrm{Kbb}$, nor does it reflect seasonal variability in their source contributions (Sect. 3.4). The modest correlation of OCbb with organic tracer-based wood-burning OC concentrations is expected due to emission source variability; overprediction of wood-burning OC by OCbb is expected during summer months when the principal biomass burning sources (agricultural field burns, open burning of wastes) likely predominate and have lower OCbb / Kbb. The sum of the Kleindienst et al. (2010) diesel and wood-burning OC concentrations correlates highly $\left(r^{2}=0.92\right)$ with OCbb and CO in a multiple regression model (Fig. S26), supporting combustion origins of OCbb.

\subsubsection{Temporal variations}

Temporal variations of the 1999-2013 PCA2 results are described here primarily for CTR and JST, representing (as in Table 1) one rural and one urban location having extensive SEARCH data records. At JST, day-of-week variations are evident for the combustion-derived $\mathrm{OC}$ and for the OC associated with crustal species (Fig. S27), consistent with the occurrence of weekly activity cycles for driving, construction, and other anthropogenic emission sources. Dayof-week variations are not apparent for other OC associations at JST or for any OC factors at CTR. Seasonal and $\mathrm{SO}_{4}$-associated $\mathrm{OC}$ exhibit pronounced monthly variations at both CTR and JST, with higher values of $\mathrm{SO}_{4}$-associated OC and of CTR seasonal OC occurring during warmer months (Figs. S28 and S29). The patterns for CTR $\mathrm{SO}_{4}$-associated OC (highest in July and August) and seasonal OC (higher in spring and autumn than in July) are not independent.

Mean annual combustion-derived OC concentrations decline from $3.8 \pm 0.2$ to $1.4 \pm 0.1 \mu \mathrm{g} \mathrm{m}^{-3}$ between 1999 and 2013 at JST (Figs. 4, S30) and from $2.9 \pm 0.4$ to $0.7 \pm 0.1 \mu \mathrm{g} \mathrm{m}^{-3}$ between 2001 and 2013 at BHM (not shown). Declining combustion OC concentrations at the urban JST and BHM sites coincide with reductions of motor vehicle emissions during this time period (Sect. 3.1), though these urban sites may also be affected by industrial emissions. BHM additionally benefits from a decline in OC associated with $\mathrm{SO}_{2}$ from $0.4 \pm 0.04 \mu \mathrm{g} \mathrm{m}^{-3}$ in 2001 to $0.2 \pm 0.03 \mu \mathrm{g} \mathrm{m}^{-3}$ in 2013, probably as a reflection of declining emissions from industrial sources within Birmingham. In contrast, combustion-derived OC at CTR does not exhibit a statistically significant decline, equaling $1.5 \pm 0.1 \mu \mathrm{g} \mathrm{m}^{-3}$ in 1999 and $1.3 \pm 0.1 \mu \mathrm{g} \mathrm{m}^{-3}$ in 2013 (Figs. 4, S30). At CTR, downward $\mathrm{OC}$ trends are evident only for $\mathrm{SO}_{4}$ and seasonal 

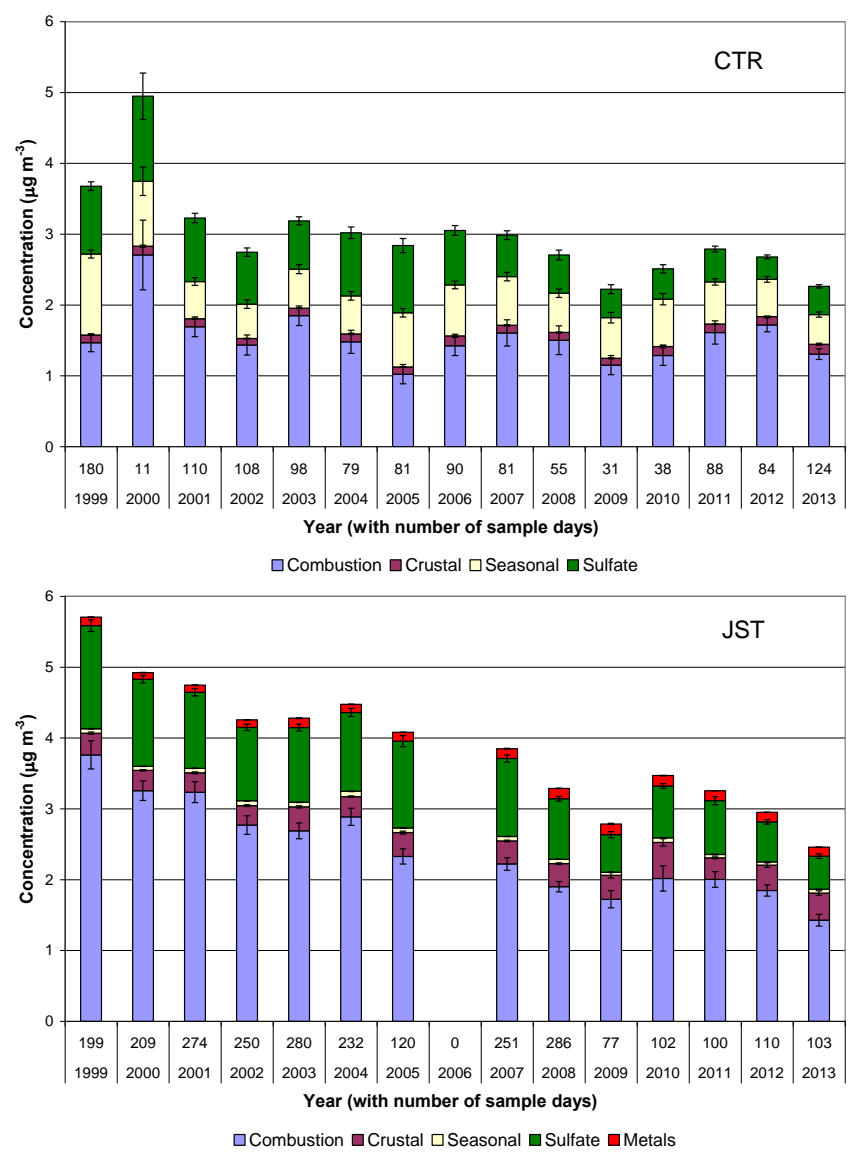

Figure 4. Trends in source contributions to OC at CTR and JST determined from PCA2 for 1999-2013.

OC (mean decreases of 0.6 and $0.7 \mu \mathrm{g} \mathrm{m}^{-3}$, respectively) (Fig. S31). The $\mathrm{OC}$ associated with $\mathrm{SO}_{4}$ at CTR exhibits declines during all seasons, with the weakest such change in winter (Fig. S32).

The trend results are consistent with the combined effects of (1) regional-scale reductions of ambient $\mathrm{SO}_{4}$ and $\mathrm{O}_{3}$ concentrations, (2) reductions of urban $\mathrm{OC}$ due to declining mobile source OC and VOC emissions, and (3) likely predominance of biomass burning OC at CTR (Hidy et al., 2014). Carbon-isotope measurements from 2004 show that fossil carbon represented $\sim 20 \%$ of CTR TC that year (Blanchard et al., 2011), indicating that mobile source or other fossil fuel emissions affect CTR to some extent. Enhanced hourly concentrations of EC, OC, and CO at CTR are associated with winds from the directions of Birmingham, Tuscaloosa, and Montgomery (Hidy et al., 2014). EC declined by $\sim 0.3 \mu \mathrm{g} \mathrm{m}^{-3}$ at CTR between 1999 and 2013 (Fig. 1), suggesting an influence of mobile source emission reductions that is possibly too modest to detect using our PCA methods or is masked by annual variability in biomass burning emissions. For comparison, mean EC concentrations at JST decrease by $\sim 1.4 \mu \mathrm{g} \mathrm{m}^{-3}$ (Fig. 1), and the overall mean EC at JST $\left(1.35 \mu \mathrm{g} \mathrm{m}^{-3}\right)$ is $\sim 4$ times the overall mean EC at CTR $\left(0.35 \mu \mathrm{g} \mathrm{m}^{-3}\right)$.

The trends in mean annual OC from each identified species association indicate that anthropogenic emission reductions decreased mean annual urban combustion OC concentrations by $2.4 \mu \mathrm{g} \mathrm{m}^{-3}$ at JST and at BHM (and, by inference, other metropolitan areas in the southeast), and indirectly decreased $\mathrm{SO}_{4}$ and seasonal $\mathrm{OC}$ by $\sim 1.1$ to $1.3 \mu \mathrm{g} \mathrm{m}^{-3}$ throughout the southeastern US between 1999 and 2013 (Fig. 4). As of 2013, the overall mean annual combustion-derived $\mathrm{OC}$ is 1.3 to $1.4 \mu \mathrm{g} \mathrm{m}^{-3}$ at CTR and JST, whereas the sum of the mean annual $\mathrm{SO}_{4}$ and seasonal-component $\mathrm{OC}$ is 0.4 to $0.8 \mu \mathrm{g} \mathrm{m}^{-3}$ at CTR and JST (Fig. 4).

\subsection{Synthesis}

Various apportionments of $\mathrm{PM}_{2.5} \mathrm{OC}$ concentrations are presented in Sect. 3.1, 3.4, and 3.5. These apportionments are compared and contrasted in this section. Although the apportionments utilize different methods, there is overlap of inputs. For example, Kbb is used as an input in the multivariate regressions that generate primary organic carbon (POC) and secondary organic carbon (SOC) (Blanchard et al., 2008, not discussed here), and POC is a fitting species used in the CMB receptor modeling. As shown in Table 5, the apportionments exhibit areas of agreement as well as certain differences. Both are summarized using ratios of the values listed in Table 5. We report averages and ranges across the sites.

Computed POC represents $72 \%$ (64-76\%) of mean OC concentrations, whereas SOC represents $29 \%$ (25-38\%). As noted, SOC is the OC that is associated with $\mathrm{O}_{3}$ and $\mathrm{SO}_{4}$, which constitutes a portion of SOA. POC is associated with $\mathrm{EC}, \mathrm{CO}$, and $\mathrm{Kbb}$, but may include oxidized OC that would be identified as SOA in other analyses. For the CMB analysis, OC derived from area sources (primarily biomass burning), mobile sources, and point sources is summed to generate combustion OC. CMB combustion OC is $97 \%(73-118 \%)$ of POC; this level of agreement presumably is because the CMB receptor model of Blanchard et al. (2013) used POC as a fitting species. The largest PCA1 and PCA2 OC components are combustion, seasonal, and $\mathrm{SO}_{4}$-associated OC. The sum of these three components is, for PCA1, $87 \%$ (60$139 \%$ ) of mean measured OC (the overestimate, at PNS, is balanced by negative crustal and salt components there). For $\mathrm{PCA} 2$, the sum of combustion, seasonal, and $\mathrm{SO}_{4}$-associated OC is $81 \%(58-101 \%)$ of mean measured OC. Other PCA OC components contribute smaller amounts (Table 5).

PCA1 and PCA2 combustion each represent $57 \%$ (8-103 and $33-85 \%$, respectively) of CMB combustion. Other PCA factors, including $\mathrm{SO}_{2}$, metals, and salts (possibly denoting biomass burning when represented by $\mathrm{K}$ ) may be related to specific types of combustion sources.

These comparisons suggest that the OCbb concentrations are likely biased high by $\sim 10 \%$ or more, with less evident biases at inland sites. Specifically, OCbb is $99 \%$ (66-121\%) 
Table 5. Mean OC concentrations determined for the period 2008-2013 using four analytical approaches: (1) multivariate regression (POC and SOC; Blanchard et al., 2008), (2) calculation of OCbb from Kbb tracer, (3) PCA and PMF analysis, and (4) CMB receptor modeling (Blanchard et al., 2013, updated). Row indentations indicate subcategories. Units are $\mu \mathrm{g} \mathrm{m}^{-3}$ unless specified as $\%$.

\begin{tabular}{|c|c|c|c|c|c|c|c|c|c|}
\hline Component & BHM & CTR & GFP & JST & OAK & OLF & PNS & YRK & $\mathrm{Unc}^{\mathrm{a}}$ \\
\hline OC (mean measured) & 2.91 & 2.41 & 1.91 & 2.86 & 1.84 & 1.81 & 2.06 & 2.33 & 0.05 \\
\hline $\mathrm{POC}^{\mathrm{b}}$ & 1.85 & 1.78 & 1.40 & 2.12 & 1.35 & 1.36 & 1.57 & 1.61 & $25 \%$ \\
\hline $\mathrm{OCbb}$ & 1.58 & 1.60 & 1.64 & 1.40 & 1.63 & 1.62 & 1.77 & 1.37 & $2 X$ \\
\hline PCA1 combustion & 1.36 & 1.28 & 0.95 & 1.07 & 0.40 & 0.85 & 1.95 & 0.13 & $0.3-0.6$ \\
\hline PCA2 combustion & 1.09 & 1.47 & 0.45 & 1.83 & 0.87 & 0.60 & 1.26 & 0.49 & $0.3-0.6$ \\
\hline PMF combustion & NA & 1.03 & NA & 1.22 & NA & NA & NA & NA & $0.3-0.6$ \\
\hline CMB combustion total & 2.54 & 1.52 & 1.33 & 2.16 & 1.42 & 1.47 & 1.89 & 1.49 & 0.87 \\
\hline CMB area sources & 2.01 & 1.44 & 1.15 & 1.50 & 1.35 & 1.34 & 1.68 & 1.35 & $20-3 \%$ \\
\hline CMB mobile diesel & 0.20 & 0.02 & 0.05 & 0.27 & 0.01 & 0.05 & 0.04 & 0.04 & $13-31 \%$ \\
\hline CMB mobile gas & 0.29 & 0.03 & 0.10 & 0.34 & 0.03 & 0.05 & 0.15 & 0.06 & $17-41 \%$ \\
\hline CMB point sources & 0.05 & 0.02 & 0.02 & 0.05 & 0.02 & 0.03 & 0.03 & 0.04 & $5-6 \%$ \\
\hline PCA1 crustal & 0.09 & 0.26 & 0.00 & 0.15 & 0.00 & -0.14 & 0.00 & 0.14 & $0.09-0.11$ \\
\hline PCA2 crustal & 0.20 & 0.12 & 0.17 & 0.35 & 0.00 & -0.06 & 0.00 & 0.22 & $0.09-0.11$ \\
\hline PMF crustal & NA & 0.09 & NA & 0.17 & NA & NA & NA & NA & $0.09-0.11$ \\
\hline CMB dust & 0.09 & 0.02 & 0.04 & 0.03 & 0.03 & 0.02 & 0.04 & 0.01 & $9-22 \%$ \\
\hline $\mathrm{SOC}^{\mathrm{b}}$ & 1.10 & 0.66 & 0.56 & 0.75 & 0.48 & 0.48 & 0.50 & 0.77 & $25 \%$ \\
\hline PCA1 seasonal + sulfate & 0.85 & 0.90 & 0.70 & 0.76 & 1.03 & 1.00 & 0.90 & 1.26 & $0.3-0.5$ \\
\hline PCA1 seasonal & 0.39 & 0.57 & 0.45 & 0.49 & 0.50 & 0.71 & 0.33 & 1.00 & $0.1-0.4$ \\
\hline PCA1 sulfate & 0.45 & 0.33 & 0.25 & 0.27 & 0.53 & 0.29 & 0.56 & 0.26 & $0.2-0.3$ \\
\hline PCA2 seasonal + sulfate & 0.92 & 0.95 & 0.81 & 0.76 & 0.99 & 0.93 & 0.41 & 0.86 & $0.3-0.5$ \\
\hline PCA2 seasonal & 0.51 & 0.53 & 0.40 & 0.05 & 0.40 & 0.28 & 0.41 & 0.86 & $0.1-0.4$ \\
\hline PCA2 sulfate & 0.42 & 0.42 & 0.41 & 0.71 & 0.58 & 0.65 & 0.00 & 0.00 & $0.2-0.3$ \\
\hline PMF seasonal + sulfate & NA & 0.77 & NA & 1.32 & NA & NA & NA & NA & $0.3-0.5$ \\
\hline PMF seasonal & NA & 0.49 & NA & 0.86 & NA & NA & NA & NA & $0.1-0.4$ \\
\hline PMF sulfate & NA & 0.28 & NA & 0.46 & NA & NA & NA & NA & $0.2-0.3$ \\
\hline $\begin{array}{l}N \text { days (2008-2013, } \\
\text { varies by analysis) }\end{array}$ & $366-1313$ & $383-606$ & $100-280$ & $443-787$ & $100-206$ & $327-598$ & $44-162$ & $426-585$ & \\
\hline
\end{tabular}

${ }^{a}$ Uncertainty for mean measured OC is 1 standard error of the mean. Uncertainties for PCA and PMF are taken from Sect. 3.5.3. Uncertainty for CMB combustion total is RMSE across sites and years, where error is defined as the difference between predicted and observed concentrations. Uncertainty for CMB components is based on uncertainties in inputs

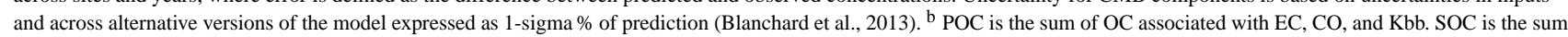
of $\mathrm{OC}$ associated with $\mathrm{O}_{3}$, and $\mathrm{SO}_{4}$. $\mathrm{POC}$ is used as a fitting species in $\mathrm{CMB}$.

of POC and $109 \%(79-142 \%)$ of CMB area-source OC concentrations. At inland sites, OCbb is $96 \%(79-111 \%)$ of CMB area-source OC concentrations, indicating approximate agreement. Although multiple analyses (OCbb, POC, PCA2) used Kbb as an input variable, OCbb is calculated using a fixed scaling factor between $\mathrm{OC}$ and $\mathrm{Kbb}$. As described, uncertainty in this scaling factor is estimated to generate a factor-of-2 uncertainty in OCbb.

\section{Conclusions}

In all, 15 years of measurements of an extensive suite of gas and particle species at eight SEARCH sites offer important insights into the sources of OA and the effects of anthropogenic emission reductions on OA concentrations in the southeastern US. Five analytical methods indicate that a major component ( $\sim 45 \%$ on average, 1999 to 2013, all sites; intersite range 25 to $63 \%$ ) of OA derives from combustion sources, including motor vehicles and biomass burning, at all urban and rural sites and throughout the year. Reductions of emissions from combustion sources decreased overall mean annual OC concentrations by $2.4 \mu \mathrm{g} \mathrm{m}^{-3}$ at JST and BHM (and, by inference, throughout the Atlanta and Birmingham metropolitan areas) between 1999 and 2013. OA is identified partly with an $\mathrm{SO}_{4}$-OA relationship $(\sim 25 \%$ of OC, on average), which is consistent with hypothesized isoprene oxidation pathways. OA is also partly identified with other seasonal atmospheric processes, including atmospheric photochemical reactions ( $\sim 20 \%$ of OC, on average). Reductions of anthropogenic emissions of $\mathrm{SO}_{2}, \mathrm{NO}_{x}$, and VOC suggest a decrease in $\mathrm{SO}_{4}$-associated $\mathrm{OC}$ and seasonal-component $\mathrm{OC}$ concentrations by $\sim 1.1-1.3 \mu \mathrm{g} \mathrm{m}^{-3}$ between 1999 and 2013 throughout the SEARCH region, implying that reductions of anthropogenic emissions affect SOA concentrations.

As of 2013, the SEARCH mean annual combustionderived OC concentrations are 1.3 to $1.4 \mu \mathrm{g} \mathrm{m}^{-3}$ at CTR and JST ( $\sim 60 \%$ of total OC), while the mean annual OC concentrations associated with the $\mathrm{SO}_{4}$ and seasonal components are 0.4 to $0.8 \mu \mathrm{g} \mathrm{m}^{-3}$ at CTR and JST $(\sim 35$ and $\sim 22 \%$, respectively). Additional attention to $\mathrm{OC}$ from combustion emissions could yield further reductions of $\mathrm{PM}_{2.5} \mathrm{OC}$ con- 
centrations, now averaging $\sim 2.5 \mu \mathrm{g} \mathrm{m}^{-3}$ in the southeastern US. Since biomass burning is a major source of OC emissions in the southeastern US, minimizing the stated extent and timing of these emissions could help improve regional air quality.

Additional work could improve quantitative assessments of source contributions. Carbon-isotope measurements of archived SEARCH samples are in process, and will provide further insight into the observed OA trends. Future research could also help define the sensitivity of the $\mathrm{SO}_{4}$-associated
$\mathrm{OC}$ and seasonal $\mathrm{OC}$ to ongoing reductions of anthropogenic $\mathrm{SO}_{2}, \mathrm{NO}_{x}$, and VOC emissions. Current research by many investigators is better defining the role of naturally occurring VOCs, including isoprene. The SOAS and SAS campaigns of June-July 2013 helped resolve uncertainties and ambiguities in OA chemistry specific to that time period. Extrapolation of the short-term results to seasonal and interannual time periods can be achieved through further analyses of long-term $\mathrm{EC}$ and $\mathrm{OC}$ monitoring data. 


\section{Appendix A: Measurement conventions and issues}

Carbonaceous aerosol is conventionally divided into EC and OC, operationally defined by measurement protocol, either by thermal differentiation or by light absorption (for clarity, protocols based on light absorption typically report data as light-absorbing carbon (LAC) or black carbon (BC), and sometimes as brown carbon $(\mathrm{BrC})$, rather than as $\mathrm{EC})$. EC is comprised of extended aromatic rings, and is characteristically refractory, insoluble, chemically inert, and light absorbing (Cappa, 2011). EC derives from combustion and is believed to be exclusively from primary emission sources, including motor vehicles, other transportation sources, industrial processes, and vegetation burning (Chow et al., 2010; Watson et al., 2011). OC is the carbonaceous component of $\mathrm{OA}$ and refers here to specific measurements, such as filterbased measurements made by thermal-optical reflectance (TOR) (Chow et al., 2005, 2007a, b). Combustion sources that emit EC also emit OC.

Organic compounds that are directly emitted in the condensed phase are typically identified as POA, whereas SOA commonly refers to organic material transferring from gases to the condensed phase through chemical transformation (Kanakidou et al., 2005). Gases of varying degrees of volatility may be oxidized and incorporated into the condensed phase (Robinson et al., 2007; Huffman et al., 2009). Chemical reactions may take place in the condensed phase in the presence of water, and partitioning by phase are key elements of uncertainty in describing SOA (e.g., Carlton and Turpin, 2013; Nguyen et al., 2015; Isaacman-VanWertz et al., 2015). Atmospheric chemical reactions involving VOCs (Hallquist et al., 2009), especially including compounds of intermediate volatility (de Gouw et al., 2011), are known to generate oxygenated reaction products on timescales of minutes to days. Secondary organic species may be associated with other secondary species, such as $\mathrm{O}_{3}$ or $\mathrm{SO}_{4}$, either through a common driver of photochemical oxidation processes or due to direct chemical relationships; this is an active area of research.

The initial aging of fresh, concentrated emissions begins with turbulent dilution seconds after hot exhaust effluent enters into the cooler atmosphere. Fine-particle evolution then takes place more slowly over nominal 5-7-day lifetimes as particles are mixed and transported, and lost by deposition. These processes are often referred to as aging of a freshly emitted aerosol. The aging processes can be chemical in nature, or may involve physical processes as well, including absorption in clouds or precipitation followed by hydrometeor evaporation.

The exceptions to the definition of SOA as material transferring from gas to condensed phases through chemical transformation include (1) volatile or semi-volatile material that condenses into aerosol without undergoing chemical transformation (Kanakidou et al., 2005), (2) gases absorbed into hydrometeors, leaving residual aerosol on evaporation, which might be understood as either POA or SOA depend- ing on absence or occurrence of chemical transformation (Kanakidou et al., 2005), and (3) material emitted in the condensed phase that undergoes chemical transformation, possibly shifting multiple times between gas and aerosol, and that appears as oxidized compounds on analysis of aerosol samples (Donahue et al., 2009). The last exception is especially ambiguous: such material may be classified as POA in an emission inventory, but be identified as SOA according to measurements designated as more oxygenated aerosol (OOA) by aerosol mass spectrometry (AMS).

Dilution sampling is routinely used to characterize exhaust emissions because it yields estimates of EC and OC at temperatures characteristic of the ambient atmosphere, but further phase exchange of POA may be expected in the real world with ongoing dilution. Photochemical chamber studies demonstrate that organic aerosol from hot exhaust emissions (e.g., diesel engine exhaust) shifts from POA to SOA dominance typically within one or more hours of photo-oxidation (Presto et al., 2014). The comparability of POA measurements from such studies to emission inventory estimates of mobile source PM is poorly characterized. For modeling, a volatility basis set (VBS) provides more realistic diluted emission estimates by recognizing that POA spans a range of volatilities, and cannot be treated as entirely non-volatile (Robinson et al., 2007; Donahue et al., 2009, 2012).

The mass concentrations of EC are approximately conserved from emission sources to receptor sites, whereas losses due to volatilization of certain $\mathrm{PM}_{2.5}$ organic compounds readily occur. OA concentrations may increase as SOA forms not only from POA vaporization, subsequent reactions and condensation, but also, perhaps predominantly, from atmospheric reactions of gas-phase precursors. OM, which includes not only carbon but also other atoms (e.g., oxygen and hydrogen) that are components of OA, is not conserved. There is no accepted measure of aging in atmospheric aerosols, but some workers have adopted OM / OC as an indicator. As POA ages, the ratio of oxygen-to-carbon typically increases, increasing the mass of OM. Aerosol aging can, therefore, increase both the $\mathrm{OM} / \mathrm{EC}$ ratio and the OC / EC ratio (by definition, EC concentrations are not expected to increase with the formation of species during aging). A graphical depiction of various categorizations of OA is shown in the Supplement (Fig. S1).

Receptor-modeling methods have identified POA source types using measurements of conservative organic tracer species (Schauer et al., 1996), indicating that motor vehicles contribute $\sim 2$ to $4 \mu \mathrm{g} \mathrm{m}^{-3}$ to annual-average OC concentrations in Atlanta (e.g., Zheng et al., 2002, 2006). SEARCH thermal desportion - gas chromatograph mass spectrometer (TD GC-MS) measurements suggest that 30 to $50 \%$ of the observed 2006 to 2010 OC trend in Atlanta, Georgia, and Birmingham, Alabama, could be due to changes in mobile source emissions (Blanchard et al., 2014a). These trends need not be entirely from changes in POA emissions; diesel SOA, for example, is an important component 
of mobile source OA (Presto et al., 2014), and is linked to EC and POA emissions. Aside from motor vehicle exhaust, biomass burning is a major source of EC and the largest source of OC emissions in the southeastern US according to emission inventories, with little evidence for substantial trend between 1999 and 2013 (Hidy et al., 2014). Carbonisotope $\left({ }^{14} \mathrm{C}\right)$ measurements at SEARCH sites indicate that on average 2 to $4 \mu \mathrm{g} \mathrm{m}^{-3}$ of $\mathrm{OC}$ is modern in origin (rural and urban sites), with $\sim 40 \%$ fossil in Atlanta and $\sim 60 \%$ fossil in Birmingham during 2004 and 2005 (Blanchard et al., 2011). Together, the measurements suggest the presence of a large modern-carbon contribution added to downwardtrending mobile source contributions (Hidy et al., 2014).

Significant emissions of VOC from vegetation, including isoprene and terpenes, occur in the southeastern US and represent a major, and possibly a dominant, source of SOA (Goldstein et al., 2009). Although incompletely quantified, SOA derived from anthropogenic and biogenic VOC products has been estimated to be $\sim 20$ to $60 \%$ of the OA observed in the southeastern US (Table S1), varying among samples and especially by season (Lim and Turpin, 2002; Zheng et al., 2006; Saylor et al., 2006; Blanchard et al., 2008). Field and laboratory work over the years has refined the chemical pathways, with evidence for both aqueous and gas-phase chemistry. Ground-level filter samples from southeastern sites have yielded expected tracers of SOA-formation chemistry from biogenic precursors (Gao et al., 2006; Surratt et al., 2007; Chan et al., 2010; Hatch et al., 2011a, b). The presence of naturally occurring VOCs, modulated by temperature and solar radiation, is expected to be roughly constant over a period of years, suggesting a near-constant level of biogenic SOA. However, isoprene concentrations appear to have increased at Atlanta-area sites between 2002 and 2012 (Hidy et al., 2014); the reason for, and significance of, this trend for SOA trends in the southeast is unclear. Interaction of biogenic and anthropogenic emissions potentially affect SOA formation (Weber et al., 2007; Shilling et al., 2013; Xu et al., 2015a); therefore, biogenic SOA trends could result from anthropogenic emission reductions.

Determination of the fraction of OC not directly attributed to sources is complicated by both the influence of atmospheric processes on emissions and the methods of measurement of OC or its components. The processing of atmospheric aerosols is exceedingly complex as a result of the chemistry of volatile and non-volatile carbon emissions and interactions between chemical and meteorological processes on multiple time and space scales. Advancing knowledge about the SOC component has been inhibited by the lack of chemical detail in long-term observations and the short-term application of more recent measurement methods. Measurements of atmospheric organic carbon as POC and SOC refer to operational definitions, including those in Fig. S1. Historically, measurements of OC and EC have relied on filter sampling and subsequent analysis for OC constituents in the laboratory. The filter sampling and recently introduced continuous methods provide different data for EC and OC as well as some identification of constituents resolved in space in time. However, their quantitative comparison remains problematic as indicated in this study. Continuing research, including method comparisons, and expanded detailed atmospheric observations will be required to resolve these uncertainties. 


\section{The Supplement related to this article is available online at doi:10.5194/acp-16-215-2016-supplement.}

Author contributions. C. L. Blanchard, G. M. Hidy, S. Shaw, K. Baumann, and E. S. Edgerton designed the study. E. S. Edgerton and $\mathrm{K}$. Baumann operated the measurement program and prepared the data sets. C. L. Blanchard carried out the statistical analyses. C. L. Blanchard and G. M. Hidy wrote the manuscript with contributions from all co-authors.

Acknowledgements. The authors thank J. Jansen, E. Knipping, and the ARA staff for their contributions to this work. Funding for the SEARCH network has come from Southern Company and the Electric Power Research Institute. We are indebted to these sponsors for supporting this unique long-term measurement program.

Edited by: N. L. Ng

\section{References}

Andreae, M. O. and Merlet, P.: Emission of trace gases and aerosols from biomass burning, Global Biogeochem. Cy., 15, 955-966, 2001

Andreae, M. O., Atlas, E., Cachier, H., Cofer III, W. R., Harris, G. W., Helas, G., Koppmann, R., Lacaux, J.-P., and Ward, D. E.: Trace gas and aerosol emissions from savanna fires, in: Biomass Burning and Global Change, edited by: Levine, J. S., MIT Press, Cambridge MA, USA, 278-295, 1996.

Atmospheric Research and Analysis (ARA): Introduction to the Southeastern Aerosol Research and Characterization (SEARCH) Network, available at: http://www.atmospheric-research.com/ studies/SEARCH/index.html (last access: 18 December 2015), 2014

Baumann, K., Flanagan, J. B., and Jayanty, R. K. M.: Fine particulate matter source apportionment for the chemical Speciation Trends Network site at Birmingham, Alabama, using Positive Matrix Factorization, J. Air Waste Manage., 58, 27-44, 2008.

Blanchard, C. L., Hidy, G. M., Tanenbaum, S., Edgerton, E., Hartsell, B., and Jansen, J.: Carbon in southeastern aerosol particles: empirical estimates of secondary organic aerosol formation, Atmos. Environ., 42, 6710-6720, 2008.

Blanchard, C. L., Hidy, G. M., and Tanenbaum, S.: NMOC, ozone, and organic aerosol in the southeastern states, 1999-2007: 1. Spatial and temporal variations of NMOC concentrations and composition in Atlanta, Georgia, Atmos. Environ., 44, 48274839, doi:10.1016/j.atmosenv.2010.08.036, 2010.

Blanchard, C. L., Hidy, G. M., and Tanenbaum, S.: NMOC, ozone, and organic aerosol in the southeastern states, 19992007: 3. Origins of organic aerosol in Atlanta, Georgia, and surrounding areas, Atmos. Environ., 45, 1291-1302, doi:10.1016/j.atmosenv.2010.12.004, 2011.
Blanchard, C. L., Tanenbaum, S., and Hidy, G. M.: Source attribution of air pollutant concentrations and trends in the Southeastern Aerosol Research and Characterization (SEARCH) network, Environ. Sci. Technol., 47, 13536-13545, doi:10.1021/es402876s, 2013.

Blanchard, C. L., Chow, J., Edgerton, E., Watson, J. G., Hidy, G. M., and Shaw, S.: Organic aerosols in the southeastern United States: speciated particulate carbon measurements from the SEARCH network, 2006-2010, Atmos. Environ., 95, 327333, doi:10.1016/j.atmosenv.2014.06.050, 2014a.

Blanchard, C. L., Tanenbaum, S., and Hidy, G. M.: Spatial and temporal variability of air pollution in Birmingham, Alabama, Atmos. Environ., 89, 382-391, doi:10.1016/j.atmosenv.2014.01.006, 2014b.

Bougiatioti, A., Stavroulas, I., Kostenidou, E., Zarmpas, P., Theodosi, C., Kouvarakis, G., Canonaco, F., Prévôt, A. S. H., Nenes, A., Pandis, S. N., and Mihalopoulos, N.: Processing of biomassburning aerosol in the eastern Mediterranean during summertime, Atmos. Chem. Phys., 14, 4793-4807, doi:10.5194/acp-144793-2014, 2014.

Budisulistiorini, S., Canagaratna, R., Croteau, P., Marth, W., Baumann, K., Edgerton, E., Show, S., Knipping E., Worsnop, D., Jayne, J., Gold, A., and Surratt, J.: Real-time continuous characterization of secondary organic aerosol derived from isoprene epoxydiols in downtown Atlanta, Georgia, using the Aerodyne Chemical Speciation Monitor, Environ. Sci. Technol., 47, 56865694, 2013.

Budisulistiorini, S. H., Li, X., Bairai, S. T., Renfro, J., Liu, Y., Liu, Y. J., McKinney, K. A., Martin, S. T., McNeill, V. F., Pye, H. O. T., Nenes, A., Neff, M. E., Stone, E. A., Mueller, S., Knote, C., Shaw, S. L., Zhang, Z., Gold, A., and Surratt, J. D.: Examining the effects of anthropogenic emissions on isoprenederived secondary organic aerosol formation during the 2013 Southern Oxidant and Aerosol Study (SOAS) at the Look Rock, Tennessee ground site, Atmos. Chem. Phys., 15, 8871-8888, doi:10.5194/acp-15-8871-2015, 2015.

Calloway, C. P., Li, S., Buchanan, J. W., and Stevens, R. K.: A refinement of the potassium tracer method for residential wood smoke, Atmos. Environ., 23, 67-69, 1989.

Cappa, C.: Measurements of Aerosol Carbon in the Atmosphere, AAAR Tutorial, 3 October 2011, AAAR 30th Annual Conference, 3-7 October 2011, Orlando, FL, USA, available at: http://www.aaar.org/index2.cfm?section=Meetings_and_ Events\&content=Archived_Meetings (last access: 18 December 2015), 2011.

Carlton, A. G. and Turpin, B. J.: Particle partitioning potential of organic compounds is highest in the Eastern US and driven by anthropogenic water, Atmos. Chem. Phys., 13, 10203-10214, doi:10.5194/acp-13-10203-2013, 2013.

Chan, M. N., Surratt, J. D., Claeys, M., Edgerton, E. S., Tanner, R. L., Shaw, S. L., Zheng, M., Knipping, E. M., Eddingsaas, N. C., Wennberg, P. O., and Seinfeld, J. H.: Characterization and quantification of isoprene-derived epoxydiols in ambient aerosol in the southeastern United States, Environ. Sci. Technol., 44, 4590 4596, 2010.

Chow, J., Watson, J., Kuhns, H., Etyemezian, V., Lowenthal, D., Crow, D., Kohl, S., Engelbrecht, J., and Green, M.: Source profiles for industrial, mobile and area sources in the Big Bend 
Regional Aerosol Visibility and Observational Study, Chemosphere, 54, 185-208, 2004.

Chow, J. C., Watson, J. G., Chen, L.-W. A., Paredes-Miranda, G., Chang, M.-C. O., Trimble, D., Fung, K. K., Zhang, H., and Zhen Yu, J.: Refining temperature measures in thermal/optical carbon analysis, Atmos. Chem. Phys., 5, 2961-2972, doi:10.5194/acp5-2961-2005, 2005.

Chow, J. C., Watson, J. G., Chen, L.-W. A., Chang, M. C. O., Robinson, N. F., Trimble, D. L., and Kohl, S. D.: The IMPROVE_A temperature protocol for thermal/optical carbon analysis: Maintaining consistency with a long-term database, J. Air Waste Manage., 57, 1014-1023, 2007a.

Chow, J. C., Yu, J. Z., Watson, J. G., Ho, S. S. H., Bohannan, T. L., Hays, M. D., and Fung, K. K.: The application of thermal methods for determining chemical composition of carbonaceous aerosols: a review, J. Environ. Sci. Heal. A, 42, 1521-1541, 2007b.

Chow, J. C., Watson, J. G., Lowenthal, D. H., Chen, L.-W. A., and Motallebi, N.: Black and organic carbon emission inventories: review and application to California, J. Air Waste Manage., 60, 497-507, doi:10.3155/1047-3289.60.4.497, 2010.

Dattner, S. and Hopke, P. (Eds.): Receptor Models Applied to Contemporary Pollutions Problems: Proceedings of a Specialty Conference, Air Pollution Control Association, Publishers Choice Book Manufacturing Co., Mars, Pennsylvania, USA, 368 pp., 1982.

de Gouw, J. A., Middlebrook, A. M., Warneke, C., Ahmadov, R., Atlas, E. L., Bahreini, R., Blake, D. R., Brock, C. A., Brioude, J., Fahey, D. W., Fehsenfeld, F. C., Holloway, J. S., Le Henaff, M., Lueb, R. A., McKeen, S. A., Meagher, J. F., Murphy, D. M., Paris, C., Parrish, D. D., Perring, A. E., Pollack, I. B., Ravishankara, A. R., Robinson, A. L., Ryerson, T. B., Schwarz, J. P., Spackman, J. R., Srinivasan, A., and Watts, L. A.: Organic aerosol formation downwind from the Deepwater Horizon oil spill, Science, 331, 1295-1299, doi:10.1126/science.1200320, 2011.

Ding, X., Zheng, M., Edgerton, E., Jansen, J., and Wang, X.: Contemporary or fossil origin: Split of estimated secondary organic carbon in the southeastern United States, Environ. Sci. Technol., 42, 9122-9128, 2008.

Donahue, N. M., Robinson, A. L., and Pandis, S. N.: Atmospheric organic particulate matter: from smoke to secondary organic aerosol, Atmos. Environ., 43, 94-106, doi:10.1016/j.atmosenv.2008.09.055, 2009.

Donahue, N. M., Kroll, J. H., Pandis, S. N., and Robinson, A. L.: A two-dimensional volatility basis set - Part 2: Diagnostics of organic-aerosol evolution, Atmos. Chem. Phys., 12, 615-634, doi:10.5194/acp-12-615-2012, 2012.

Edgerton, E. S., Hartsell, B. E., Saylor, R. D., Jansen, J. J., Hansen, D. A., and Hidy, G. M.: The Southeastern Aerosol Research and Characterization Study: part 2 - filter-based measurements of $\mathrm{PM}_{2.5}$ and $\mathrm{PM}_{\text {coarse }}$ mass and composition, J. Air Waste Manage., 55, 1527-1542, 2005.

Edgerton, E. S., Hartsell, B. E., Saylor, R. D., Jansen, J. J., Hansen, D. A., and Hidy, G. M.: The Southeastern Aerosol Research and Characterization Study, part 3: continuous measurements of fine particulate matter mass and composition, J. Air Waste Manage., 56, 1325-1341, 2006.
Gao, S., Surratt, J., Knipping, E., Edgerton, E., Shahgholi, M., and Seinfeld, J.: Characterization of polar organic compounds in fine aerosols in the southeastern United States: identity, origin and evolution, J. Geophys. Res., 111, D14314, doi:10.1029/2005JD006601, 2006.

Goldstein, A. H., Koven, C. D., Heald, C. L., and Fung, I. Y.: Biogenic carbon and anthropogenic pollutants combine to form a cooling haze over the southeastern United States, P. Natl. Acad. Sci. USA, 106, 8835-8840, doi:10.1073/pnas.0904128106, 2009.

Guo, H., Xu, L., Bougiatioti, A., Cerully, K. M., Capps, S. L., Hite Jr., J. R., Carlton, A. G., Lee, S.-H., Bergin, M. H., Ng, N. L., Nenes, A., and Weber, R. J.: Fine-particle water and $\mathrm{pH}$ in the southeastern United States, Atmos. Chem. Phys., 15, 5211-5228, doi:10.5194/acp-15-5211-2015, 2015.

Haines, T. K., Busby, R. L., and Cleaves, D. A.: Prescribed burning in the South: trends, purpose, and barriers, South. J. Appl. For., 25, 149-153, 2001.

Hallquist, M., Wenger, J. C., Baltensperger, U., Rudich, Y., Simpson, D., Claeys, M., Dommen, J., Donahue, N. M., George, C., Goldstein, A. H., Hamilton, J. F., Herrmann, H., Hoffmann, T., Iinuma, Y., Jang, M., Jenkin, M. E., Jimenez, J. L., Kiendler-Scharr, A., Maenhaut, W., McFiggans, G., Mentel, Th. F., Monod, A., Prévôt, A. S. H., Seinfeld, J. H., Surratt, J. D., Szmigielski, R., and Wildt, J.: The formation, properties and impact of secondary organic aerosol: current and emerging issues, Atmos. Chem. Phys., 9, 5155-5236, doi:10.5194/acp-9-51552009, 2009.

Hand, J., Schichtel, B., Pitchford, M., Malm, W., and Frank, N.: Seasonal composition of remote and urban fine particulate matter in the United States, J. Geophys. Res.-Atmos., 117, DO5209, doi:10.1029/2011JD017122, 2012.

Hansen, D.A., Edgerton, E. S., Hartsell, B. E., Jansen, J. J., Hidy, G. M., Kandasamy, K., and Blanchard, C. L.: The Southeastern Aerosol Research and Characterization Study (SEARCH): 1. overview, J. Air Waste Manage., 53, 1460-1471, 2003.

Hatch, L. E., Creamean, J. M., Ault, A. P., Surratt, J. D., Chan, M. N., Seinfeld, J. H., Edgerton, E. S., Su, Y., and Prather, K. A.: Measurements of isoprene-derived organosulfates in ambient aerosols by aerosol time-of-flight mass spectrometry, part 1: single particle atmospheric observations in Atlanta, Environ. Sci. Technol., 45, 5105-5111, 2011a.

Hatch, L. E., Creamean, J. M., Ault, A. P., Surratt, J. D., Chan, M. N., Seinfeld, J. H., Edgerton, E. S., Su, Y., and Prather, K. A.: Measurements of isoprene-derived organosulfates in ambient aerosols by aerosol time-of-flight mass spectrometry, part 2: temporal variability \& formation mechanisms, Environ. Sci. Technol., 45, 8648-8655, 2011b.

Hidy, G. M., Blanchard, C. L., Baumann, K., Edgerton, E., Tanenbaum, S., Shaw, S., Knipping, E., Tombach, I., Jansen, J., and Walters, J.: Chemical climatology of the southeastern United States, 1999-2013, Atmos. Chem. Phys., 14, 11893-11914, doi:10.5194/acp-14-11893-2014, 2014.

Hobbs, H, Reid, J. S., Herring, J. A., Nance, J. D., Weiss, R. E, Ross, J. L., Hegg, D. A., Ottmar, R. D., and Liousse, C.: Particle and trace-gas measurements in the smoke from prescribed burns of forest products in the Pacific northwest, in: Biomass Burning and Global Change, edited by: Levine, J. S., MIT Press, Cambridge MA, USA, 607-715, 1996. 
Hu, W. W., Campuzano-Jost, P., Palm, B. B., Day, D. A., Ortega, A. M., Hayes, P. L., Krechmer, J. E., Chen, Q., Kuwata, M., Liu, Y. J., de Sá, S. S., McKinney, K., Martin, S. T., Hu, M., Budisulistiorini, S. H., Riva, M., Surratt, J. D., St. Clair, J. M., Isaacman-Van Wertz, G., Yee, L. D., Goldstein, A. H., Carbone, S., Brito, J., Artaxo, P., de Gouw, J. A., Koss, A., Wisthaler, A., Mikoviny, T., Karl, T., Kaser, L., Jud, W., Hansel, A., Docherty, K. S., Alexander, M. L., Robinson, N. H., Coe, H., Allan, J. D., Canagaratna, M. R., Paulot, F., and Jimenez, J. L.: Characterization of a real-time tracer for isoprene epoxydiols-derived secondary organic aerosol (IEPOX-SOA) from aerosol mass spectrometer measurements, Atmos. Chem. Phys., 15, 11807-11833, doi:10.5194/acp-15-11807-2015, 2015.

Huffman, J. A., Docherty, K. S., Mohr, C., Cubison, M. J., U1brich, I. M., Ziemann, P. J., Onasch, T. B., and Jimenez, J. L.: Chemically-resolved volatility measurements of organic aerosol from different sources, Environ. Sci. Technol., 43, 5351-5357, 2009.

Isaacman-VanWertz, G., Goldstein, A., Yee, L., Kreisberg, N., Wernis, R., Moss, J., Hering, S., de Sa, S., Martin, S., Alexander, L., Palm, B., Hu, W., Campuzano-Jost, P., Day, D., Jiminez, J., Riva, M., Surratt, J., Edgerton, E., Baumann, K., Viegas, J., Manzi, A., deSouza, R., and Artaxo, P.: Biogenic oxidation products that dominate secondary organic aerosol in forested environments actively partitioning between gas and particle phases, submitted, 2015.

Kanakidou, M., Seinfeld, J. H., Pandis, S. N., Barnes, I., Dentener, F. J., Facchini, M. C., Van Dingenen, R., Ervens, B., Nenes, A., Nielsen, C. J., Swietlicki, E., Putaud, J. P., Balkanski, Y., Fuzzi, S., Horth, J., Moortgat, G. K., Winterhalter, R., Myhre, C. E. L., Tsigaridis, K., Vignati, E., Stephanou, E. G., and Wilson, J.: Organic aerosol and global climate modelling: a review, Atmos. Chem. Phys., 5, 1053-1123, doi:10.5194/acp-5-1053-2005, 2005.

Kim, P. S., Jacob, D. J., Fisher, J. A., Travis, K., Yu, K., Zhu, L., Yantosca, R. M., Sulprizio, M. P., Jimenez, J. L., CampuzanoJost, P., Froyd, K. D., Liao, J., Hair, J. W., Fenn, M. A., Butler, C. F., Wagner, N. L., Gordon, T. D., Welti, A., Wennberg, P. O., Crounse, J. D., St. Clair, J. M., Teng, A. P., Millet, D. B., Schwarz, J. P., Markovic, M. Z., and Perring, A. E.: Sources, seasonality, and trends of southeast US aerosol: an integrated analysis of surface, aircraft, and satellite observations with the GEOS-Chem chemical transport model, Atmos. Chem. Phys., 15, 10411-10433, doi:10.5194/acp-15-10411-2015, 2015.

Kleindienst, T., Jaoui, M., Lewandowski, M., Offenburg, J., Lewis, C., Bhave, P., and Edney, E.: Estimates of the contribution of biogenic and anthropogenic hydrocarbons to secondary organic aerosol at a southeastern US location, Atmos. Environ., 41, 8288-8300, 2007.

Kleindienst, T., Lewandowski, M., Offenburg, J., and Edney, E.: Contribution of primary and secondary sources of organic aerosol and $\mathrm{PM}_{2.5}$ at SEARCH network sites, J. Air Waste Manage., 60, 1388-1399, 2010.

Kroll, J., Ng, N., Murphy, S., Flagan, R., and Seinfeld, J.: Secondary organic aerosol formation from isoprene photooxidation, Environ. Sci. Technol., 40, 1869-1877, 2006.

Landis, M. S., Lewis, C. W., Stevens, R. K., Keeler, G. J., Dvonch, J. T., and Tremblay, R. T.: Ft. McHenry tunnel study: source profiles and mercury emissions from diesel and gasoline powered vehicles, Atmos. Environ., 41, 8711-8724, doi:10.1016/j.atmosenv.2007.07.028, 2007.

Lee, D., Balachandran, S. Pachon, J., Shankaran, R., Lee, S., Mulholland, J. A., and Russell, A. G.: Ensemble-trained $\mathrm{PM}_{2.5}$ source apportionment approach for health studies, Environ. Sci. Technol., 43, 7023-7031, 2009.

Lee, S., Baumann, K., Schauer, J. J., Sheesley, R. J., Naeher, L. P., Meinardi, S., Blake, D. R., Edgerton, E. S., Russell, A. G., and Clements, M.: Gaseous and particulate emissions from prescribed burning in Georgia, Environ. Sci. Technol., 39, 9049 9056, 2005.

Lewandowski, M., Piletic, I., Kleindienst, T., Offenburg, J., Beaver, M., Jaoui, M., Docherty, K., and Edney, E.: Secondary organic aerosol characterization at field sites across the United States during the spring-summer period, Int. J. Environ. An. Ch. 93, 1084-1103, 2013.

Lewis, C. W.: Determining the sources of particulate and VOC pollutants in ambient air by radiocarbon $\left({ }^{14} \mathrm{C}\right)$ measurements, Sixth International Conference, Preservation of Our World in the Wake of Change, 30 June-4 July 1996, Jerusalem, Israel, 1996.

Lewis, C. W., Baumgardner, R. E., and Stevens, R. K.: Contribution of woodsmoke and motor vehicle emissions to ambient aerosol mutagenicity, Environ. Sci. Technol., 22, 968-971, 1988.

Lewis, C. W., Norris, G. A., Conner, T. L., and Henry, R. C.: Source apportionment of Phoenix $\mathrm{PM}_{2.5}$ aerosol with the UNMIX receptor model, J. Air Waste Manage., 53, 325-338, doi:10.1080/10473289.2003.10466155, 2003.

Lewis, C. W., Klouda, G., and Ellenson, W.: Radiocarbon measurement of the biogenic contribution to summertime $\mathrm{PM}_{2.5}$ ambient aerosol in Nashville, TN, Atmos. Environ. 38, 6053-6061, 2004

Liao, J., Froyd, K., Murphy, D., Keutsch, F., Yu, G., Wennberg, P., St. Clair, J., Crounse, J., Wisthaler, A., Mikoviny, T., Jiminez, J., Campuzano-Jost, P., Day, D., Hu, W., Ryerson, T., Pollack I., Peischl, J., Anderson, B., Ziemba, L., Blacke, D., Meinhardi, S., and Diskin, G.: Airborne measurements of organosulfates over the continental U.S., J. Geophys. Res.-Atmos., 120, 2990-3005, doi:10.1002/2014JD022378, 2015.

Lim, H. and Turpin, B.: Origins of primary and secondary organic aerosol in Atlanta: results of time-resolved measurements during the Atlanta Supersite experiment, Environ. Sci. Technol., 36, 4489-4496, 2002.

Lin, Y.-H., Knipping, E. M., Edgerton, E. S., Shaw, S. L., and Surratt, J. D.: Investigating the influences of $\mathrm{SO}_{2}$ and $\mathrm{NH}_{3}$ levels on isoprene-derived secondary organic aerosol formation using conditional sampling approaches, Atmos. Chem. Phys., 13, 84578470, doi:10.5194/acp-13-8457-2013, 2013.

Lin, Y.-H., Budisulistiorini, S., Chu, K., Siejack, R., Zhang, H., Riva, M., Zhang, Z., Gold, A., Kautzman, K., and Surratt, J.: Light-absorbing oligomer formation in secondary organic aerosol from reactive uptake of isoprene epoxidiols, Environ. Sci. Technol., 48, 12012-12021, doi:10.1021/es503142b, 2014.

Malm, W. C., Day, D., Kreidenweis, S., Collett, J., Carrico, C., McMeeking, G., and Lee, T.: Hygroscopic properties of an organic-laden aerosol, Atmos. Environ., 39, 4969-4982, 2005.

May, A., Saleh, R., Hennigan, C., Donahue, N., and Robinson, A.: Volatility of organic molecular markers used for source apportionment analysis: measurements and implications for atmospheric lifetime, Environ. Sci. Technol., 46, 12435-12444, 2012. 
McDonald, B., Goldstein, A., and Harley, R.: Long-term trends in California mobile source emissions and ambient concentrations of black carbon and organic aerosol, Environ. Sci. Technol., 49, 5178-5188, 2015.

McDonald, J. D., Chow, J. C., Peccia, J., Liu, Y., Chand, R., Hidy, G. M., and Mauderly, J. L.: Influence of collection region and site type on the composition of paved road dust, Air Qual. Atmos. Health, 6, 615-628, doi:10.1007/s11869-013-0200-4, 2013.

Murphy, B. and Pandis, S.: Exploring summertime organic aerosol formation in the eastern United States using a regional-scale budget approach and ambient measurements, J. Geophys. Res.Atmos. 115, D24216, doi:10.1029/2010JD014418, 2010.

Nguyen, E. R., Capps, S., and Carlton, A.: Decreasing aerosol water with OC trends in the southeast U.S., Environ. Sci. Technol. 49, 7843-7850, 2015.

Pachon, J. E., Balachandran, S., Hu, Y., Weber, R. J., Mulholland, J. A., and Russell, A. G.: Comparison of SOC estimates and uncertainties from aerosol chemical composition and gas phase data in Atlanta, Atmos. Environ., 44, 3907-3914, 2010.

Pachon, J. E., Weber, R. J., Zhang, X., Mulholland, J. A., and Russell, A. G. Revising the use of potassium $(\mathrm{K})$ in the source apportionment of $\mathrm{PM}_{2.5}$, Atmos. Pollut. Res., 4, 14-21, 2013.

Pandis, S., Paulson, S., Seinfeld, J., and Flagan, R.: Aerosol formation in the photooxidation of isoprene and b-pinene, Atmos. Environ. 25A, 1997-1991, 1991.

Presto, A. A., Gordon, T. D., and Robinson, A. L.: Primary to secondary organic aerosol: evolution of organic emissions from mobile combustion sources, Atmos. Chem. Phys., 14, 5015-5036, doi:10.5194/acp-14-5015-2014, 2014.

Provencher, L., Herring, B. J., Gordon, D. R., Rodgers, H. L., Tanner, G. W., Hardesty, J. L., Brennan, L. A., and Litt, A. R.: Longleaf pine and oak responses to hardwood reduction techniques in fire-suppressed sandhills in northwest Florida, Forest Ecol. Manag., 148, 63-77, 2001.

Reff, A., Bhave, P., Simon, H., Pace, T. S., Pouliot, G. A., Mobley, D., and Houyoux, M.: Emissions inventory of $\mathrm{PM}_{2.5}$ trace elements across the United States, Environ. Sci. Technol., 43, 5790-5796, 2009.

Reid, J. S., Koppmann, R., Eck, T. F., and Eleuterio, D. P.: A review of biomass burning emissions part II: intensive physical properties of biomass burning particles, Atmos. Chem. Phys., 5, 799825, doi:10.5194/acp-5-799-2005, 2005.

Robinson, A. L., Donahue, N. M., Shrivastava, M. K., Weitkamp, E. A., Sage, A. M., Grieshop, A. P., Lane, T. E., Jeffrey R. Pierce, J. R., and Pandis, S. N.: Rethinking organic aerosols: semivolatile emissions and photochemical aging, Science, 315, 1259-1262, doi:10.1126/science.1133061, 2007.

Saylor, R. D., Edgerton, E. S., and Hartsell, B. E.: Linear regression techniques for use in the EC tracer method of secondary organic aerosol estimation, Atmos. Environ., 40, 7546-7556, 2006.

Schauer, J. J., Rogge, W. F., Hildemann, L. M., Mazurek, M. A., and Cass, G. R.: Source apportionment of airborne particulate matter using organic compounds as tracers, Atmos. Environ., 30, 3837-3855, 1996.

Shilling, J. E., Zaveri, R. A., Fast, J. D., Kleinman, L., Alexander, M. L., Canagaratna, M. R., Fortner, E., Hubbe, J. M., Jayne, J. T., Sedlacek, A., Setyan, A., Springston, S., Worsnop, D. R., and Zhang, Q.: Enhanced SOA formation from mixed anthropogenic and biogenic emissions during the CARES campaign,
Atmos. Chem. Phys., 13, 2091-2113, doi:10.5194/acp-13-20912013, 2013.

Surratt, J., Kroll, J., Kleindinst, T., Edney, E., Claeys, M., Sorooshian, A., Ng, N., Offenberg, J., Lewandowski, M., Jaoui, M., Flagan, R., and Seinfeld, J.: Evidence for organosulfates in secondary organic aerosol, Environ. Sci. Technol., 41, 517-527, 2007.

Tang, I. N.: Chemical and size effects of hygroscopic aerosols on light scattering coefficients, J. Geophys. Res., 101, 1924519250, 1996.

Tanner, R., Parkhurst, W., and McNichol, A.: Fossil sources of ambient aerosol carbon based on ${ }^{14} \mathrm{C}$ measurements, Aerosol Sci. Technol., 38, 133-139, 2004.

Taylor, N. F., Collins, D. R., Spencer, C. W., Lowenthal, D. H., Zielinska, B., Samburova, V., and Kumar, N.: Measurement of ambient aerosol hydration state at Great Smoky Mountains National Park in the southeastern United States, Atmos. Chem. Phys., 11, 12085-12107, doi:10.5194/acp-11-12085-2011, 2011.

Tombach, I.: Estimating Particle-Bound Water in Weighed Sulfate and Nitrate Particles Collected in the Southeast, in preparation for Southern Company, 2004.

Turpin, B. J. and Lim, H.-J.: Species contributions to $\mathrm{PM}_{2.5}$ mass concentrations: revisiting common assumptions for estimating organic mass, Aerosol Sci. Technol., 25, 602-610, 2001.

EPA: Positive Matrix Factorization (PMF) 5.0 Fundamentals and User Guide, EPA/600/R-14/108, availabe at: http://www.epa.gov/sites/production/files/2015-02/documents/ pmf_5.0_user_guide.pdf (last access: 18 December 2015), April 2014.

Varner III, J. M., Gordon, D. R., Putz, F. E., and Hiers, J. K.: Restoring fire to long-unburned Pinus palustris ecosystems: novel fire effects and consequences for long-unburned ecosystems, Restor. Ecol., 13, 536-544, 2005.

Wade, D. D., Brock, B. L., Brose, P. H., Grace, J. B., Hoch, G. A., and Patterson, W. A.: Fire in eastern ecosystems, in: Wildland Fire in Ecosystems: Effects of Fire on Flora, USDA Forest Service, edited by: Brown, J. K. and Smith, J. K., Rocky Mountain Research Station, Gen. Tech. Rep. RMRS-42, Ogden, UT, USA, available at: http://www.treesearch.fs.fed.us/pubs/4554 (last access: 18 December 2015), 2000.

Washenfelder, R., Attwood, A., Brock, C., Guo, H., Xu, L., Weber, R., Ng, N., Allen, H., Ayres, B., Baumann, K., Cohen, R., Draper, C., Duffey, K., Edgerton, E., Fry, J., Jiminez, J., Palm, B., Romer, P., Stone, E., Woodridge, P., and Brown, S.: Biomass burning dominates brown carbon absorption in the rural southeastern United States. Geophys. Res. Lett., 42, 653-664, doi:10.1002/2014GL062444, 2015.

Watson, J. G., Chow, J. C., Chen, L.-W. A., Lowenthal, D. H., Fujita, E. M., Kuhns, H. D., Sodeman, D. A., Campbell, D. E., Moosmüller, H., and Zhu, D. Z.: Particulate emission factors for mobile fossil fuel and biomass combustion sources, Sci. Total Environ., 409, 2384-2396, 2011.

Watson, J. G., Chow, J. C., Lowenthal, D. H., Chen, L.-W. A., Shaw, S., Edgerton, E. S., and Blanchard, C. L.: PM $_{2.5}$ source apportionment with organic markers in the Southeastern Aerosol Research and Characterization (SEARCH) study, J. Air Waste Manage., 65, 1104-1118, doi:10.1080/10962247.2015.1063551, 2015. 
Weber, R. J., Sullivan, A. P., Peltier, R. E., Russell, A., Yan, B., Zheng, M., de Gouw, J., Warneke, C., Brock, C., Holloway, J. S., Atlas, E. L., and Edgerton, E.: A study of secondary organic aerosol formation in the anthropogenicinfluenced southeastern United States, J. Geophys. Res., 112, D13302, doi:10.1029/2007JD008408, 2007.

Xu, L., Guo, H., Boyd, C. M., Klein, M., Bougiatioti, A., Cerully, K. M., Hite, J. R., Isaacman-VanWertz, G., Kreisberg, N. M., Knote, C., Olson, K., Koss, A., Goldstein, A. H., Hering, S., de Gouw, J., Baumann, K., Lee, S.-H., Nenes, A., Weber, R., and Ng, N. L.: Effects of anthropogenic emissions on aerosol formation from isoprene and monoterpenes in the southeastern United States, P. Natl. Acad. Sci. USA, 112, 37-42, doi:10.1073/pnas.1417609112, 2015a.

Xu, L., Suresh, S., Guo, H., Weber, R. J., and Ng, N. L.: Aerosol characterization over the southeastern United States using highresolution aerosol mass spectrometry: spatial and seasonal variation of aerosol composition and sources with a focus on organic nitrates, Atmos. Chem. Phys., 15, 7307-7336, doi:10.5194/acp15-7307-2015, 2015b.
Yu, S., Bhave, P., Dennis, R., and Mathur, R.: Seasonal and regional variations of primary and secondary organic aerosols over the continental United States: semi-empirical estimates and model evaluation, Environ. Sci. Technol., 41, 4690-4697, 2007.

Zhang, X., Hecobian, A., Zheng, M., Frank, N. H., and Weber, R. J.: Biomass burning impact on $\mathrm{PM}_{2.5}$ over the southeastern US during 2007: integrating chemically speciated FRM filter measurements, MODIS fire counts and PMF analysis, Atmos. Chem. Phys., 10, 6839-6853, doi:10.5194/acp-10-6839-2010, 2010.

Zheng, M., Cass, G. R., Schauer, J. J., and Edgerton, E. S.: Source apportionment of $\mathrm{PM}_{2.5}$ in the southeastern United States using solvent-extractable organic compounds as tracers, Environ. Sci. Technol., 36, 2361-2371, 2002.

Zheng, M., Ke, L., Edgerton E. S., Schauer, J. J., Dong, M., and Russell, A. G.: Spatial distribution of carbonaceous aerosol in the southeastern United States using molecular markers and carbon isotope data, J. Geophys. Res., 111, D10S06, doi:10.1029/2005JD006777, 2006. 